\title{
Mitigation And CURRENT MANAgement ATtempts To Limit Pathogen Survival ANd Movement WITHIN FARMED GRASSLAND
}

\author{
David M. Oliver ${ }^{1}$, A. Louise Heathwaite ${ }^{1}$, Chris J. Hodgson ${ }^{2}$ \\ and David R. Chadwick ${ }^{2}$
}

\footnotetext{
1 Centre for Sustainable Water Management, Lancaster Environment Centre, Lancaster University, Lancaster, UK, LA1 4YQ

2 Institute of Grassland and Environmental Research, North Wyke Research Station, Okehampton, Devon, UK, EX20 2SB
}

\section{INTRODUCTION}

II. SOURCES OF PATHOGENS IN THE FARM ENVIRONMENT
A. Manures spread to land
B. Grazing animals
C. Manure spreading $v s$ grazing as a source
D. Farmyards and animal feeding operations

III. REDUCING PATHOGEN NUMBERS VIA MANURE MANAGEMENT
A. Solid Manures
B. Liquid Manures
C. Livestock Welfare

IV. LAND MANAGEMENT STRATEGIES TO LIMIT PATHOGEN TRANSFER FROM LAND TO WATER

A. Measures to reduce pathogen mobilization from land B. Measures to reduce pathogen delivery to water

V. SYNTHESIS AND CONCLUDING REMARKS
A. Conceptualizing microbial mitigation
B. Conclusions 


\begin{abstract}
To successfully curb microbial contamination of surface waters we need to understand, and holistically evaluate, the range of mitigation strategies that have been designed to protect watercourses from non-point agricultural sources, so as to use them to best effect. A cost-effective and pragmatic approach is to improve knowledge of farm management operations capable of (i) reducing potential pathogen numbers in livestock manures and (ii) reducing subsequent transfer (through the environment) of fecal micro-organisms derived from livestock manures that are recycled to land. This will prove important for supporting farmer decision making, devising policy and implementing mitigation practices to limit fecal micro-organism delivery from land to water. In this chapter, we consider a diverse suite of manure, animal and land management options that range from simple manure composting techniques and the use of slurry additives, through to land mana gement engineering approaches and the design of constructed wetlands to protect watercourses from microbial contamination. The choice as to which strategy to use, if any, is ultimately made by the farmer and is likely to be influenced by a complex range of factors which may include, for example, tradition, convenience and farm economics. We conclude that the inherent complexity associated with heterogeneous landscapes confounds the likelihood that a single management strategy will provide complete protection of receiving waters from microbial contamination. Instead, the coupling of different strategies alongside improved education and considerable vigilance by farmers and land-owners is needed for a more sustainable approach to limiting diffuse microbial (and, crucially, other contaminant) pollution from agriculture.
\end{abstract}

\title{
KEY WORDS
}

agriculture; animal manure; non-point source pollution; land management; livestock grazing manure management; mitigation; pathogens; source; transfer 


\section{INTRODUCTION}

In agricultural catchments, the export of microbial contaminants from diffuse sources occurs when bacteria, protozoa and viruses are mobilised from locations within or upon soil, and then transported to watercourses. This potential for microbial pollution of surface waters is exacerbated within farmed catchments (Wither et al., 2005a; Pickup et al., 2005; Crowther et al., 2003; Crowther et al., 2002; Crowther et al., 2001; Kay et al., 1999) largely as a result of the recycling of livestock excreta to land either by grazing animals or applications of organic manures. The ramifications are that agricultural practices have the potential to contaminate surface waters with enteric micro-organisms, a proportion of which may be pathogenic to humans. Thus, water-borne illness and the associated ease of transmission of a variety of pathogenic micro-organisms via watercourses remain of significant importance despite the potential risks associated with land applied livestock manures having been recognized for more than 100 years (Gerba and Smith, 2005).

In Europe, legislation such as the Bathing Waters Directive (76/160/EEC) (Anon, 1976) has acted to drive improvements in sewage treatment, sewerage infrastructure and compliance with mandatory bathing water quality regulations. Similarly in the U.S., the microbiological quality of beach water is required to be of a safe standard as established by the USEPA. Unfortunately, non-compliance with microbial guidelines can still occur at designated bathing sites, particularly after high rainfall, and this has been attributed, in part, to diffuse sources contributed from agricultural land (Crowther et al., 2002). In winter months or for significant summer storms, heavy rainfall primarily drives high water flow conditions and so the transport of fecally derived microbes through catchments can be of a highly episodic nature (Wilkinson et al., 2006) which adds to the complexity of tackling catchment scale microbial pollution of watercourses. Diffuse pollutants sourced from farmed areas are likely to come under increased scrutiny following the implementation of both the EU Water Framework Directive (2000/60/EC) (Anon, 2000) and cross compliance associated with Common Agricultural Policy (CAP) reform. Furthermore, in the case of European legislation, the Bathing Waters Directive is soon to be updated, with microbial standards set to get tougher and compliance at bathing beaches predicted to fall as a result (Jones, 2002).

In a move to curb the potential increase in designated bathing waters failing to meet future mandatory standards, a cost-effective and pragmatic option is to improve understanding of farm management operations capable of (i) reducing potential pathogen numbers in livestock excreta and manures and (ii) reducing subsequent transfer (through the environment) of fecal micro-organisms derived from livestock excreta that are recycled to land. This will prove important for supporting farmer decision making, devising policy and implementing mitigation practices to limit fecal micro-organism delivery from land to water. Figure 1 synthesises these points in a basic conceptual framework. 


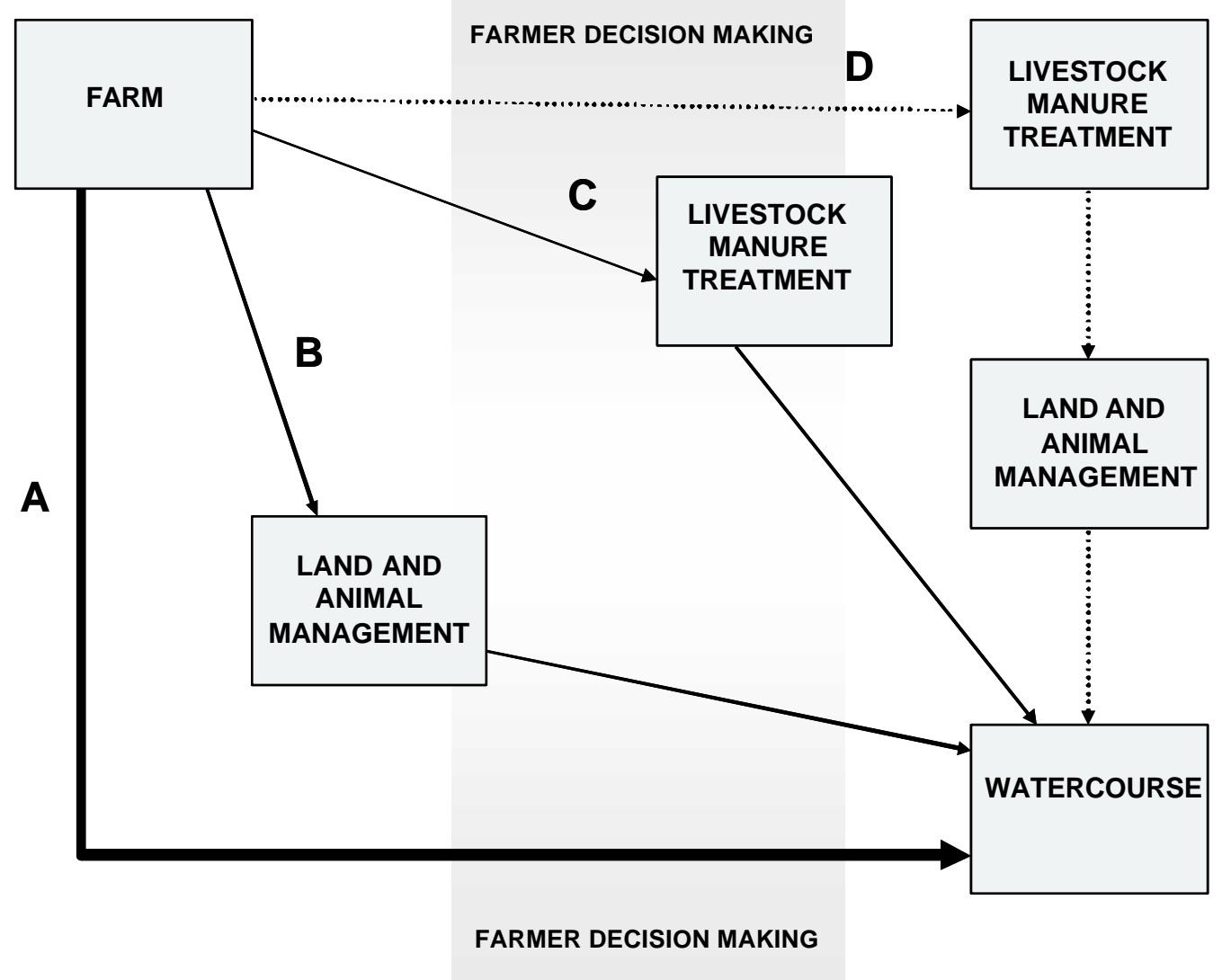

Figure 1: Approaches available to limit delivery of potential pathogens to receiving waters. Route A represents no vigilance on the part of the farmer, any reduction is a result of environmental and microbial processes. Route B suggests land and animal management techniques are employed such as fencing off water courses from grazing animals or applying manures at acceptable times via appropriate application methods. Some farms may choose route $\mathrm{C}$ and compost or process animal manures to the detriment of microbial populations. Farms showing a willingness to protect the environment are likely to combine benefits of both land and animal manure management for maximum effect (route D). An overarching influence is the decision making process embedded within individual farmers. The weight of the line associated with each route denotes a simple level of relative risk of potential contamination of adjacent watercourses.

The aims of this review are two-fold. First, to assess current measures (available to farmers and landowners) capable of limiting and reducing fecal micro-organism numbers within manures which accumulate on farms (i.e. targeting the source of pathogens). Secondly, to assess proactive land management options capable of limiting microbial movement from grassland soils to watercourses. As an initial strategy, mitigation efforts can attempt to limit the mobilisation of fecally derived contaminants once they are received by land, and a secondary option is to focus efforts on limiting the delivery of manure-borne microbes to a watercourse through 'disconnecting' hydrological connectivity. Mitigation efforts can therefore focus on source, mobilization and delivery aspects of pathogen cycling through the environment and each of these components is dealt with in this chapter in accordance 
with a 'source-mobilization-delivery' concept (illustrated in Fig 2). The conceptual model shown in Figure 2 has been adopted for many types of contaminants and is as equally applicable for microbial pollutants.

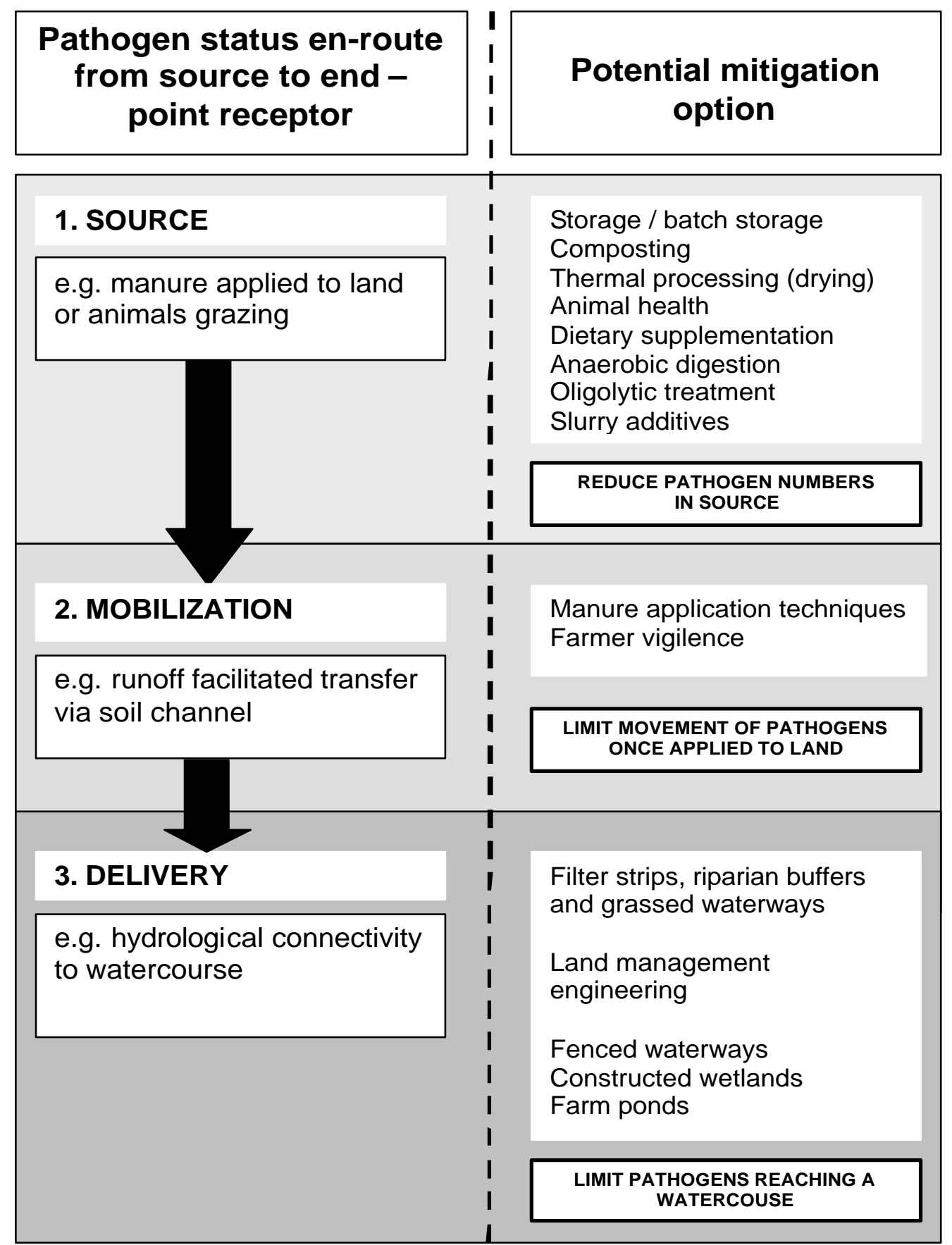

Figure 2: Conceptual model of pathogen stage transition through the environment via source, mobilization and delivery. Mitigation efforts for preventing pathogen contamination of watercourses will target one or more of the 3 components of the source - mobilisation delivery model. 


\section{SOURCES OF PATHOGENS IN THE FARM ENVIRONMENT}

Within this review the term manure will be used when describing both solid and liquid animal manures; slurry will refer specifically to liquid manures, and the term solid manure used generically to describe cattle and pig farmyard manure (FYM) and poultry manure. A common misdemeanour is to perceive and to refer to such animal by-products as animal wastes which is misleading and instead we should recognise manures to be a farm resource (Burton and Turner, 2003). Although a valuable farm resource, excretions from livestock can be a substantial source of pathogens to the environment; a study in the U.K. has suggested that over $30 \%$ of livestock manures (derived from cattle, pigs, sheep and poultry) contain at least one form of microbial pathogen (Hutchison et al., 2004a). The survival of fecally derived micro-organisms within farm manures has been reviewed previously by Oliver et al., (2005a). Consequently, the following evaluation focuses upon sources of potential pathogens commonly found within farms environments and agricultural land.

\section{A. MANURES SPREAD TO LAND}

\section{Slurry (liquid manure)}

Slurry is a relatively uniform mix of excrement and urine produced by housed livestock and collected in a liquid form (Chadwick and Chen, 2002) with a typical dry matter content ranging between $1-10 \%$ (Pain and Menzi, 2003). Slurry may also contain parlour washings, dilution water and secretions from the animal's nose, throat, blood, mammary gland, skin and placenta (Pell, 1997). It flows under gravity and can be collected via slatted floor systems within animal housing which empty into reception pits. This liquid manure is then spread to land to provide replenishment of nutrients for plant growth. Intensification of livestock agriculture in the UK has favoured the production of slurry over solid manure because of the reduced use of bedding materials (Strauch and Ballarini, 1994). All European member states prevent the spreading of slurries within nitrate vulnerable zones (NVZs) during an autumn closed period in an attempt to protect watercourses. In the U.S., animal feeding operations (AFOs) are regulated in accordance with farm size (based on 'animal units'), with larger AFOs constrained by greater regulation, based on the assumption that larger operations pose a greater pollution risk (Risse et al., 2005).

Slurries contain a host of microbes that are derived from the gut of farm animals and accommodate a more uniform microbial distribution when compared with solid manure because of the greater mobility of micro-organisms in this liquid material (Chadwick and Chen, 2002). There is noted to be seasonal variability in pathogen numbers found in slurries. As an example, higher counts of Camplyobacter have been recorded in cooler winter months within stored dairy slurry on farms in Lancashire, UK (Stanley et al., 1998). In the UK, slurry storage often consists of above ground cylindrical tanks (made either of steel or concrete) or slurry lagoons and is often a mixture of old material and newly deposited manure. Storage capacity varies with farming activity, financial investment and the amount of rain water that is able to access the store. Covered slurry stores are advantageous because less precipitation is able to contribute to the accumulation of the liquid fraction of the slurry, limiting both the amount of manure required for recycling back to land and the potential for overflowing. Improper sealing of all valves or a crack developing in the store wall could potentially lead to water and soil contamination of extensive proportions. An 
alternative system to slurry storage tanks are lagoons. These comprise a pit in the ground and can be either lined with concrete or be earth walled. Similarly, lagoons are generally open to rainfall.

\section{Solid manure (farmyard manure; FYM)}

In contrast to slurry, solid manure cannot flow under gravity. But due to its solid form it is easily stacked. Specifically, FYM is made up of livestock excretions combined with a bedding material (generally straw). It is common practice for broiler chickens to be bedded on woodshavings, thus generating broiler litter. In the short term, solid manure is generally piled into heaps that accumulate within the farmyard though Nicholson et al., (1999) suggest that only $21 \%$ of solid manure is stored permanently on concrete in England and Wales. More often, solid manure is transferred to a field and stored as a field heap until spread to land. Within England and Wales, the practice of leaving uncovered manure heaps in fields until a more appropriate time for application (Fig 3A) is common, and this method accounts for $79 \%$ of solid manure storage (Nicholson et al., 1999). This acts to free up space within farmyards and can improve the convenience of spreading manure at a later date. However, high intensity rainfall that occurs prior to spreading may provide the driving force to facilitate the transfer of microbes from uncovered manure heaps to nearby watercourses.

Consequently, careful thought needs to be given as to where to best situate field heaps in order to minimise the risk of water pollution. The solid fraction of the manure heap (Fig 3A(i)) can generate a liqueur that seeps out of the bottom of the manure pile (Fig $3 \mathrm{~A}(\mathrm{ii})$ ) and this may either infiltrate slowly through the soil profile and provide a vehicle for vertical microbe transfer or transfer over the surface of sloping land. A large liquid fraction can be generated when manure heaps are left uncovered outside and so good agricultural practice would require that such heaps are not located above field drains or within $10 \mathrm{~m}$ of a watercourse (MAFF, 1998).
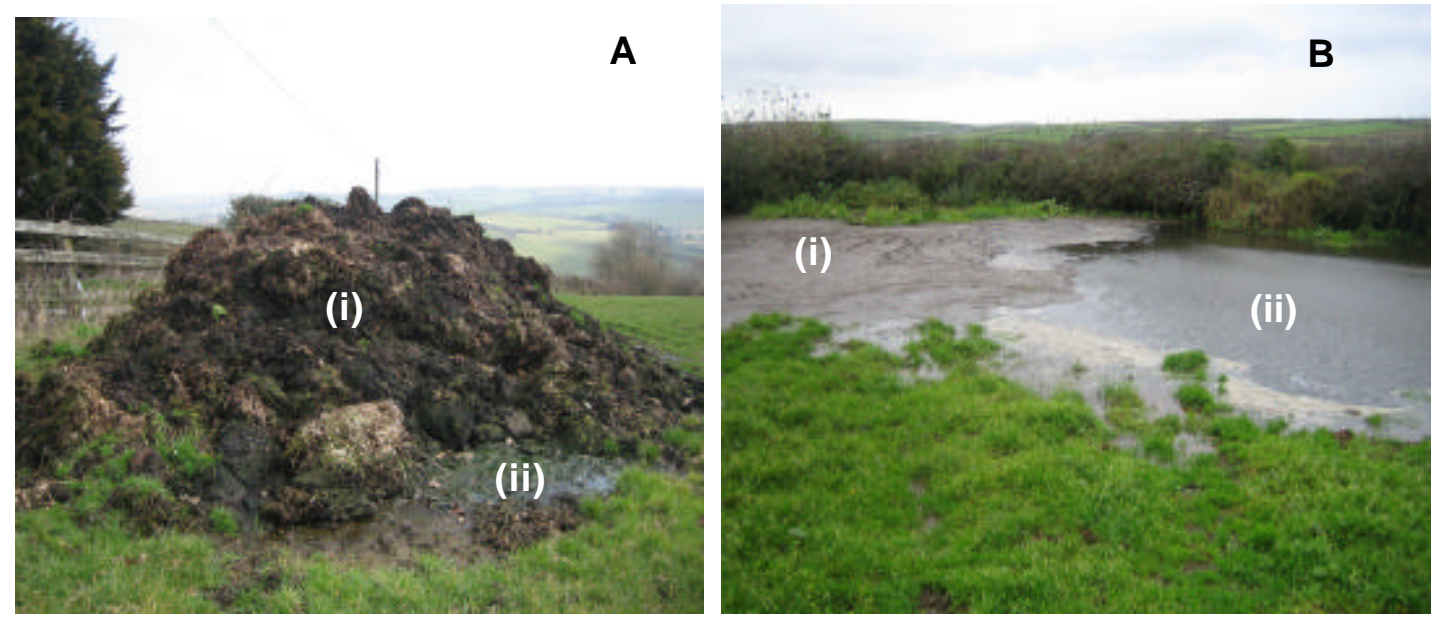

Figure 3: Typical examples of temporary field stores on farms in North Devon, UK. Photo A shows (i) an uncovered manure heap with (ii) resulting manure liquor drainage and photo B shows a dirty water soak-away [(i) solid and (ii) liquid fraction] (Photograph A taken by D. Oliver, photograph B taken by C. Hodgson). 


\section{Dirty water}

Any form of water that has been contaminated with feces or urine may be termed dirty water and is generally of a dry matter consistency of less than $3 \%$. Dirty water can accumulate following the washing down of agricultural machinery, parlour floors and concrete yards areas but also following the generation of runoff across hardstandings used by livestock. In particular, large quantities of dirty water can accumulate on dairy farms in areas of high rainfall (Smith et al., 2001). Additionally, seepage from slurry, FYM and silage stores often drains to dirty water stores on farms. Weeping wall lagoons can be used to fractionate off a liquid compone nt of slurries and solid manures and this liquid fraction, containing greater nutrient and organic matter concentrations than dirty water, is then often pumped from a collection tank to a sprinkler system that distributes this liquid to land. Pathogens such as E. coli O157, Campylobacter and Salmonella have been reported to survive for up to 3 months in stored dirty water (Nicholson et al., 2005) highlighting that even though this is a more dilute form of farm manure, it can represent an additional source of pathogens and fecally derived microbes to agricultural land. Codes of good agricultural practice (CoGAP) stipulate that pollution to surface water caused by dirty water can be minimised if facilities are in place to store and manage this farming byproduct and if warning devices and automatic cut-offs for sprinkler devices are checked and maintained (MAFF, 1998). Though sprinkler systems are a common method of distributing dirty water to land an alternative approach adopted by some farmers is to accommodate a dirty water soak-away within the farm (Fig 3B). In doing so, dirty water is collected and then pumped from a holding lagoon to another field and left to soak-away through the natural filter of the soil matrix. The solid (Fig 3B(i)) and liquid (Fig 3B(ii)) components of the dirty water are separated during the soakaway process. Clearly, if combined with heavy rainfall, and if situated in a location whereby surface runoff could facilitate transfer, poorly designed soak-aways represent a significant risk to surface water quality.

\section{B. GRAZING ANIMALS}

All grazing animals defecate onto pasture and their deposited feces contain large quantities of enteric bacteria and potentially a number of pathogenic microbes. The volume of excreta deposited to pasture varies with animal type, size and age. Typical volumes of excreta voided by a $550 \mathrm{~kg}$ dairy cow, $500 \mathrm{~kg}$ beef cow, $180 \mathrm{~kg}$ beef bullock, $65 \mathrm{~kg}$ mature sheep and $35 \mathrm{~kg}$ lamb are estimated to be 53, 32, 13, 4.1 and 1.1 litres day ${ }^{-1}$, respectively (MAFF, 1998). Pasture that becomes contaminated with feces from grazing animals may facilitate the spread of a pathogen throughout uninfected animals should other grazers ingest microbes from the sward (Judge et al., 2005). Thelin and Gifford (1983) and Avery et al. (2004b) have suggested that fecal deposits appear to provide a protective niche for the long term survival of indigenous bacteria and the physical crusting of feces can contribute to the lengthy persistence of some bacteria outside the animal gut. Grazing rejection patches which result from a higher sward height around deposited dung on grazing fields (Bao et al., 1998; Norman and Green, 1958) can increase the shade surrounding feces and may bring 
some relief from the detrimental effects of UV radiation to potentially prolong bacterial survival on pasture (Meays et al., 2005).

While cattle, both dairy and beef, are considered important reservoirs of pathogenic $E$. coli, a comparative study identified that for fresh manures from cattle and sheep, $E$. coli $\mathrm{O} 157$ had an incidence of $13.2 \%$ and $20.9 \%$ within bovine and ovine manure, respectively (Hutchison et al., 2004b). The same study identified that within fresh manures, sheep were found to accommodate a higher incidence of Salmonella, Campylobacter, Cryptosporidium parvum and Giardia intestinalis than cattle (Hutchison et al., 2004b). In sheep, Cryptosporidium has been identified as having an increasingly important role in neonatal diarrhoea syndrome and is currently associated with high morbidity rates for these animals (de Graaf et al., 1999). While farmers can take steps to limit this occurrence by using pre-lambing vaccinations, this may lead to different risks associated with contamination associated with veterinary medicines reaching water bodies or contaminating soils. A study in Spain found that the most frequent aetiologic agent involved in outbreaks of diarrhoea in lambs was $C$. parvum (65\% of outbreaks and $45 \%$ of the individuals) (Munoz-Fernandez et al. 1996) and Xiao et al. (1993) suggested that ewes were an important source of infection for lambs following an outbreak of diarrhoea in neonatal lambs in northern Ohio whereby $100 \%$ of newborn lambs were affected. Similarly, colonised neonatal lambs have been reported to have excreted in excess of $6.5 \times 10^{7}$ viable Cryptosporidium oocysts per gram of feces in the first 10 days of birth (Svoboda et al., 1997). In contrast, a recent study has questioned the role of sheep as important zoontotic reservoirs for Cryptosporidium and Giardia (Ryan et al., 2005) following findings that around 98\% and $76 \%$ of Cryptosporidium and Giardia isolates, respectively, isolated in a study were not known to infect humans. However, a limitation of the Ryan et al. (2005) research was that pre-weaned lambs were excluded from the study and it is acknowledged that $C$. parvum may be the most prevalent species in pre-weaned lambs. As a final comment, it should be recognised that livestock markets can facilitate contact between infected herds and the subsequent transportation of animals suggests that widespread dissemination of microbes is feasible (Fèvre et al., 2006).

\section{MANURE SPREADING VS GRAZING AS A SOURCE}

In comparing sources of fecal microbes derived from manure spreading and animal grazing periods, Figure 4 shows a conceptual model that contrasts the input and decline of $E$. coli, on pasture, for a single broadcast slurry application versus a single grazing season. The profile of $E$. coli decline within each livestock manure type is simplified but based on literature (Oliver et al., 2005b; Oliver, 2005). The initial number of E. coli on pasture is shown to be high for slurry (Fig 4; Scenario A) because the livestock manure is applied to a greater area of pasture than that covered by fecal deposits at time zero (i.e. the beginning of the grazing season). By contrast, the grazing season (Fig 4; Scenario B) is shown to provide an accumulating E. coli input to pasture via sporadic fecal deposition over a greater time-period than a single slurry application. Numbers of $E$. coli on pasture then decline following the removal of grazing cattle at the end of the grazing season. Clearly the 'risk window' available for surface water contamination is more limited for a one-off manure application to pasture than for the grazing season In addition, the loading of land with E. coli derived from slurry is likely to be considerably lower if batch-stored, as opposed to fresh slurry is applied to land (Hutchison et al., 2005a) (see Section III.B.1). The 
increased 'risk window' for potential bacterial contamination of surface waters associated with grazing is also likely to coincide with the bathing season $\left(15^{\text {th }}\right.$ May $30^{\text {th }}$ September) in Europe. Therefore, a summer storm that occurs several months into a grazing period may have considerable impact on bacteriological quality of bathing water located near agricultural land at a time of critical importance in respect to water quality monitoring.

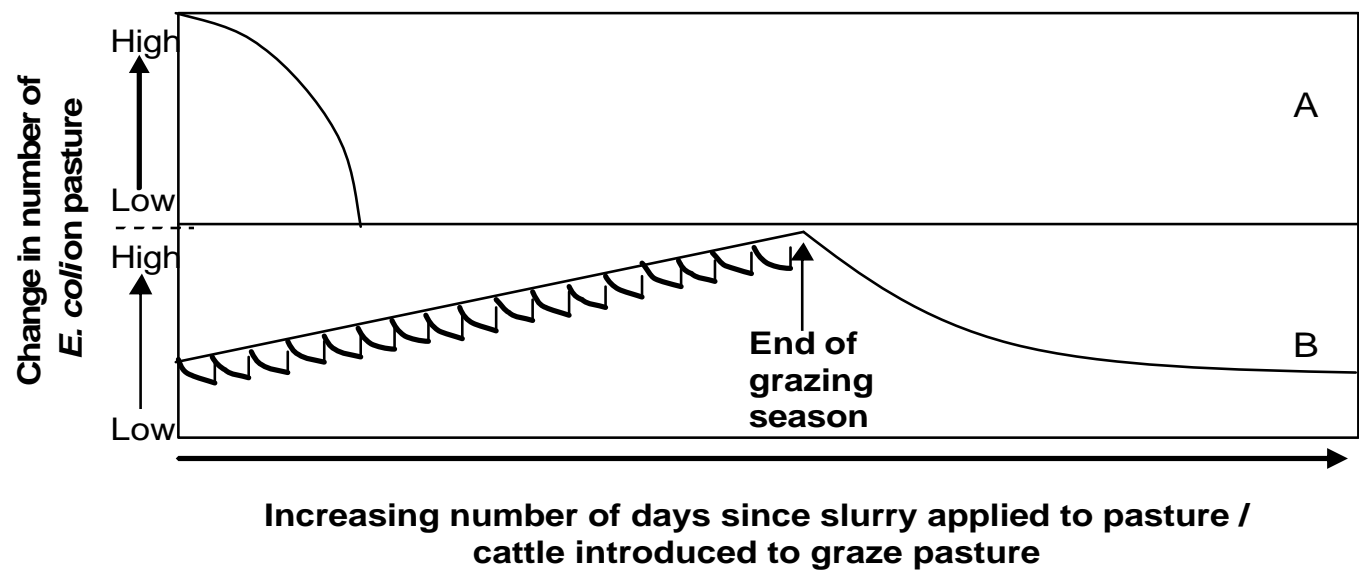

\section{Potential for E. coli transfer to surface waters given appropriate hydrological drivers High Low}

Figure 4: Conceptual diagram highlighting potential change in $E$. coli numbers within slurry applied (A) and fresh faeces deposited (B) to pasture. The change in the potential for bacterial contamination of surface waters, given appropriate hydrological drivers (e.g. a storm event), is shown. The black lines depict generalised die-off curves.

A drained clay loam plot experiment in Scotland found that the risk of E. coli loss from land grazed by sheep exceeded that associated with slurry applications during autumn / spring and wet summer conditions (Vinten et al., 2004a). Complementary findings have been reported by Soupir et al. (2006), whereby feces deposited on pasture by grazing livestock had a greater potential to contribute high bacterial concentrations to watercourses than the application of liquid dairy manure. However, factors such as stocking density, grazing season duration and manure application rates will all play a role in determining the overall microbial pollution potential to nearby receiving waters. The conceptual model shown in Figure 4, along with the two studies described here, highlight that it is essential to focus mitigation efforts on losses from grazing animals in addition to losses attributed to manure spreading. 


\section{FARMYARDS and ANIMAL FEEDING OPERATIONS}

A survey in England and Wales of 471 dairy farmers and 515 beef farmers indicated that in general dairy farms generate manures in the form of $65 \%$ slurry and $35 \%$ FYM compared with $80 \%$ FYM and 20\% slurry upon beef farms (Smith et al., 2001). Farmyards may constitute a significant source of microbial pathogens, largely because they are often the hub of farming activity and accommodate retention systems for holding the manures which are deposited within the farmyard. This is particularly pertinent for dairy farms whereby a single dairy cow $(550 \mathrm{~kg})$ is likely to produce 9.7 $\mathrm{m}^{3}$ of liquid manure over a 6 month housing period compared with $5.8 \mathrm{~m}^{3}$ from a single $500 \mathrm{~kg}$ beef cow (Burton and Turner, 2003). Farmyards can accommodate milking parlours, housed animals and manure storage facilities and these tend to be structured on hard-standings of concrete or a non porous material that can result in runoff of contaminated water at a rapid rate following storm events (Edwards and Merrilees, 2003). The farmyard will often be host to animal movement s or act to confine animals in limited space, and can be used to allow daily exercise for dairy cows which often need to be kept close to the milking parlour (Lewis et al., 2005). Stressful conditions associated with movement and limited space may result in high quantities of manures being deposited by animals (Friend, 1991). Farmyards are always drained to some extent, and this may allow for direct hydrological connectivity from the farmyard to a nearby watercourse. Goss et al. (1994a) claimed that in Canada, ammonia and bacteria contributions to watercourses are of lesser concern than phosphorus $(\mathrm{P})$, because their release from storage facilities could be controlled by appropriate management practices. Clearly then, poor management of stored manures and animals confined within the farmyard will result in a more substantial threat of environmental pollution. In the US, AFOs are a significant potential source of microbial pathogens, generating around $100 \times$ more waste than wastewater treatment plants (Gerba and Smith, 2005), and that does not include the manure produc ed by grazing animals.

Leaking septic tanks are often regarded as potential point sources of pollution and they can represent an additional source of fecal microbes that originate close to the farmyard. Direct evidence has shown, using biochemical fingerprinting of fecal indicator bacteria, that septic systems can at times fail and then act as a potential source of pathogens to surface waters (Ahmed et al., 2005). Septic tank leakages are not specific to farms though, as many rural homes would also accommodate such domestic waste systems. Additionally, within catchments, other contributions to microbial loadings of watercourses are likely to arise from human sewage discharges, wildlife and urban drainage.

\section{REDUCING PATHOGEN NUMBERS VIA MANURE MANAGEMENT}

Manure that undergoes a thorough treatment process prior to land application can be an effective and safe organic fertilizer whereas those manures that are not treated represent a potential microbial hazard if combined with hydrological connectivity to a watercourse. An evaluation of current methods used to promote pathogen and fecal microbe die-off in livestock manures revealed a varied selection of approaches, each with associated costs and benefits. Techniques range from simple and cheap pragmatic approaches of manure management through to complex techniques that require high capital and running costs and which, in some cases, would require 
external contractors, rather than a solitary farm, to deal with livestock manures. Briefly, the methods addressed in the following section include manure storage, aeration techniques (liquid composting and solids composting), liming and the use of other slurry additives, oligolytic (or electrolytic) methods, pasteurisation, anaerobic digestion techniques and dietary supplementation. The choice as to which treatment to use, if any, is ultimately made by the farmer and is likely to be influenced by a complex range of factors which may include, for example, tradition, convenience and farm economics.

\section{A. SOLID MANURES}

\section{Solid manure storage}

In the UK, guidance is provided for the handling and storage of livestock manures via the Department for Environment, Food and Rural Affairs CoGAP for protection of water (MAFF, 1998). In the UK, solid farm manures are typically stored for periods of 3-6 months prior to land application (Smith et al., 2000) and storage is commonplace primarily because much manure is produced over winter while animals are housed and pasture is unavailable for grazing, but also because collected manures cannot be recycled to land in one application in order to achieve the greatest benefit for the farmer and the land. Additionally, compliance with CoGAP would prevent the spreading of livestock manure to land under certain circumstances, for example, during or following heavy rainfall (MAFF, 1998) - though this does not necessarily mean such practices are strictly adhered to by all farmers because it is often difficult to gauge the unpredictable nature of weather. Thus, storage of livestock manure on some farms is a necessity and at the same time manures can undergo an improvement in their microbiological quality through potential reduction of fecal micro-organism numbers as a function of time. For those farms that are unable to store manures due to limited storage capacity, the alternative and sometimes more convenient option is that they are forced to spread straight to land (Smith et al., 2001). In doing so the farmer bypasses a microbe reduction period (related to time) and spreads fresh manure (containing higher concentrations of faecal microbes) onto pasture.

The observed decline in pathogen numbers in stored solid manure over time is dependent on management and storage conditions (Nicholson et al., 2005) but it is generally understood that the microbial population in excreta experiences considerable change during storage. Factors influencing microbial fluctuations in solid manure include, for example, temperature (Hutchison et al., 2005b; Himathongkham et al., 1999), aeration (Forshell and Eskebo, 1993), and competing microbes (Jones et al., 1977). Storage of solid livestock manures can result in a heat generating composting processes whereas, in contrast, untreated slurries stored in tanks or lagoons are likely to remain at ambient temperature. However, even at low temperatures, time will result in a general decline of microbes (Maule, 1999). Storage of solid manure heaps in locations exposed to UV (e.g. Fig 3A), such as in fields or farmyards without any protective covering, are also likely to experience a more rapid decline in the numbers of microbes because of the detrimental impact of sunlight. However, manure heaps may become saturated if exposed to rainfall and this can result in poor conditions for facilitating effective composting of solid manure (see III.A.2). Provided there is enough bedding material to allow good airflow then extended storage is not required for FYM and in any case, manure heaps are often left 
in excess of 90 days due to normal farming practice and this should be sufficient for significant pathogen reduction.

\section{Composting}

Composting is an exothermic process that involves the decomposition of organic wastes within a warm, moist, aerobic environment via a suite of microorgansims (Forshell and Ekesbo, 1993) and which provides numerous advantages to manures. These can include: reduced odour (Hobbs et al., 2004) and biological oxygen demand (BOD), reductions in manure volume (Burton and Turner, 2003) and nitrogen (N) control (Michel et al., 2004) alongside the potential for fecal micro-organism reduction. Simple solid manure storage should result in composting but by using manure management techniques the efficiency of this process can be enhanced. The efficiency of any composting system is related to a number of variables including, for example, straw content, moisture content and the frequency of manure turning (Nicholson et al., 2000) and so not all composting is successful in (i) attaining high temperatures (around $55^{\circ} \mathrm{C}$ ) and therefore (ii) reducing fecal microbe numbers effectively. The inactivation of pathogens is promoted when composting reactors are used, equipped with adequate insulation so that walls also reach high temperatures and prevent the formation of areas of low temperature (Vinneras et al., 2003). Composting is limited by oxygen presence and so an adequate air supply is a prerequisite for microbes in order to decompress mass and avoid anaerobic conditions (Mohaibes and Heinon-Tanski, 2004). Agitation of solid manure assists in supplying oxygen to the heap to promote successful composting. A common composting technique is termed static pile composting and involves a heap of manure being placed upon a porous layer of straw or woodchips in order to maximise air distribution within the manure heap. To avoid forced aeration via manual turning of manure heaps it has been suggested that the use of a minimum of $2.5 \mathrm{~kg}$ of straw per cow (and day) must be used to provide a manure that can self compost (Forshell and Ekesbo, 1993). Thermal insulation may then be achieved using a covering layer of mature compost or by using an amount of material large enough to achieve self insulation (Finstein, 2004). An alternative to static pile composting is windrow composting whereby long rows of solid manure (approximately $3 \mathrm{~m}$ wide and $1.5 \mathrm{~m}$ high, but can vary) are periodically turned to provide aerobic conditions. An historical perspective of the evolution of composting technology is available (Fitzpatrick et al., 2005).

Solids composting is able to generate much more heat than liquid composting because the exothermic processes lose less heat through dissipation within the solid livestock manure. Temperatures as high as $75^{\circ} \mathrm{C}$ have been reported during solids composting (Svoboda, 2003). The composting of green waste (garden and park waste) for 3 days at a temperature of $55^{\circ} \mathrm{C}$ has been suggested to be efficient for pathogen removal (Jones and Martin, 2003). Tiquia et al., (1998) provide an account of windrow composting of pig manure and sawdust; the pathogen Salmonella was successfully eradicated after temperatures of $64-67^{\circ} \mathrm{C}$ were reached and maintained for 2-3 weeks. Similarly, windrow composting of beef cattle feedlot manure bedded with either cereal straw or wood chips was found to reduce total coliforms (TC) and E. coli by over $99.9 \%$ in only 7 days after temperatures of up to $42^{\circ} \mathrm{C}$ were attained (Larney et al., 2003). The bedding type did not affect bacterial elimination and although temperature was clearly a key determinant in coliform kill, the authors speculated that 
the observed decline may also be a function of antagonism from aerobic heterotrophic bacterial populations. Other work has reported that thermophilic windrow composting at temperatures in excess of $55^{\circ} \mathrm{C}$ for a period of 15 days is sufficient to result in a significant decline of Cryptosporidium and Giardia (oo)cysts (Van Herk et al., 2004).

Solid manures of high moisture content will not compost as efficiently as dry manures (Finstein, 2004; Nicholson et al., 2000). Seasonal fluctuations in temperature are therefore likely to affect composting efficiency and hence manure heaps composted over winter months have the potential to harbour disease causing microbes for longer periods. Manure composting using laboratory stored heaps (at $20^{\circ} \mathrm{C}$ and $37^{\circ} \mathrm{C}$ ) facilitated a $\log _{10}$ reduction in E. coli $\mathrm{O} 157$ numbers within 13.5 and 3.6 days respectively (Himathongkham et al., 1999). Another study, at ambient temperatures, was able to isolate $E$. coli $\mathrm{O} 157$ from small aerated bovine FYM heaps for up to 47 days and for up to 4 months from small aerated ovine FYM heaps (Kudva et al., 1998). However, because it is difficult to ascertain the heat distribution throughout concentrated slurry and manure it is advised that safety margins for time be used if composting is used to destroy pathogens (Mohaibes and Heinonen-Tanski, 2004). Nicholson et al. (2005) reported that most pathogen types were eliminated within 1 week within solid manure heaps under composting conditions that reached over $55^{\circ} \mathrm{C}$. Others have reported that the movement of livestock bedding manure heaps from pens to a storage location, where temperatures are likely to rise, can prove effective for reduction of pathogen numbers (Hutchison et al. 2005b). This is a simple and cheap method for lowering pathogen levels in solid manure and one which reflects routine agricultural practice.

Not only direct effects of increased temperature contribute to the decline of potential pathogens. In addition the composting of a material containing a high $\mathrm{N}$ supply is likely to result in the release of free ammonia which is detrimental to micro-organism persistence (Finstein, 2004; Svoboda, 2003). Solid manure composting represents a viable approach to implement on farms in the UK and abroad due to its simplicity and low running costs and capital expenditure. Even turning a manure heap only once can encourage aeration of the heap and can lead to large reductions in fecal microbe numbers.

\section{Thermal processing (drying)}

Successful thermal processing of solid manure should result in moisture removal from, and volume reduction of, manures (Pain and Menzi, 2003). Part of the natural drying process involves draining of "manure tea" (which can contain fecalbacteria) as the heap becomes compressed under its own weight. Sterilization of manure can be achieved if conditions allow the process to work at optimal efficiency and the technique has been found to be more reliable for manures of a higher dry matter content (e.g. poultry manure). At present it is not a widely adopted approach based on the grounds of cost to dry FYM (Hutchison, pers. comm.). 


\section{B. LIQUID MANURES}

\section{Slurry storage}

The survival of enteric microbes and potential pathogens has been extensively detailed using studies at a variety of scales. The impact of storage time of slurry on generic and pathogenic E. coli populations has been shown via batch experimentation by Oliver (2005) and Himathongkham et al. (1999), respectively. However, when scaling up to the farm management level, slurry tanks are often filled over a timecourse and, as a consequence, the reduction effects of storage are negated due to introduction of fresh slurry to the store which inoculates the liquid livestock manure with a new supply of viable micro-organisms. This suggests that ideally a farm needs more than one slurry store to prevent re-contamination of stored slurry and facilitate batch storage. It is therefore worrying that a risk assessment study of 117 farms carried out in two river catchments in south west Scotland identified that $21 \%$ of farmers had less storage than 1 month of the farm's manure production (Aitken, 2003). Only $29 \%$ had more than 5 months storage and over $50 \%$ of the farms were found to have inadequate or unsatisfactory manure storage facilities in terms of risk of water pollution incidents (Aitken, 2003). A survey of England and Wales likewise identified that $23 \%$ of beef and dairy farms combined had no or minimal slurry storage suggesting these farms may pose an increased risk of storage overflow (Smith et al., 2001).

The extent of reduction via storage varies between studies. A batch experiment using five different cattle slurries demonstrated that for all slurries, E. coli $\mathrm{O} 157$ declined steadily, though at significantly different rates, but after 64 days, in most cases, E. coli O157 was still detectable (Avery et al., 2005). Avery et al. (2005) conducted the experiments at $10^{\circ} \mathrm{C}$ to reflect the mean annual air and soil temperature as experienced in North Wales. Work reported by Oliver (2005) showed that generic $E$. coli declined to undetectable levels $\left(<130 \mathrm{CFU} \mathrm{mL}^{-1}\right)$ as early as day 42 , representing a $6 \log _{10} \mathrm{CFU}$ reduction, when stored in slurry at $15^{\circ} \mathrm{C}$. While it is accepted that generic $E$. coli, as an indicator of potential pathogen presence, must survive at least as well as pathogenic strains, it is likely that the more rapid decline observed by Oliver (2005) in comparison with Avery et al. (2005) is governed, in part, by the higher experimental temperature used. Early work of Jones et al., (1976) highlighted a rapid reduction in Salmonella dublin in cattle slurry during the first month of storage and the rate of decline corresponded with increasing temperature. During the months June to December and at temperatures of generally less than $20^{\circ} \mathrm{C}$, E. coli $\mathrm{O} 157$, Salmonella spp. and Campylobacter spp. have been shown to survive for up to 3 months (Nicholson et al., 2005).

Another study evaluated the survival times of E. coli and Salmonella in slurry. These were reported to be a maximum of 1 week and 28 weeks, respectively (Kovacs and Tamasi, 1979). Under these experimental conditions Salmonella was observed to persist 7 times longer at $20^{\circ} \mathrm{C}$ than at $4^{\circ} \mathrm{C}$. This again highlighted the role of temperature dependent destruction kinetics, however, the more lengthy persistence in this study was associated with a higher temperature treatment which is contradictory to much of the other published research. It was speculated in a recent review by Oliver et al., (2005a), that the lower temperatures may have induced a viable but nonculturable (VBNC) state in the Salmonella spp. and so may have allowed for the 
Salmonella cells to avoid detection. The VBNC state means that the microbes remain metabolically active but are no longer able to grow and divide on conventional media and thus do not produce colonies. As a result the Salmonella count at the low temperature may have been an underestimate.

In a comparison of bacterial and protozoan pathogen die-off within slurry the protozoa Cryptosporidium parvum was found to be much more robust than bacterial cells (Hutchison et al., 2005a). This research found that after inoculation of pathogens into $35,000 \mathrm{~L}$ volumes of fresh livestock manure, the decimal reduction time ( $D$ values; time for a $1 \log _{10}$ drop) for bacterial pathogens ranged between 6 and 44 days whereas $C$. parvum had a maximum $D$-value of 345 days. No distinct effect of seasonality on decline of micro-organisms under storage was observed (Hutchison et al., 2005a).

Generally, it is found that batch storage of livestock manures provides a useful and simple strategy for reducing the enteric micro-organism content, but it is considerably more expensive than standard storage because of the extra batch storage capacity needed (Chambers, 2003). Storage is also beneficial because it means that manures can be spread to land when the risk of surface runoff is less. However, some researchers believe that long term storage is not the answer for complete destruction of pathogenic E. coli within manure (Avery et al., 2005). Others have suggested that livestock manures, if contaminated with bacterial pathoge ns, should undergo storage duration of 6 months to reduce pathogen levels though alternative strategies should be explored to reduce viable levels of protozoan pathogens (Hutchison et al., 2005a). The results of a recent report similarly concluded that an extensive length of storage (6 months or greater) is required to reduce bacteria numbers by $99 \%$ (Svoboda, 2003).

Unfortunately, storage of slurry for long periods can result in anaerobic conditions that will usually give rise to offensive odours in farming environments and release methane and ammonia to the atmosphere (Zanardini et al., 2002). In fact, stored livestock manure derived from cattle accounts for significant (around 10\% of total) $\mathrm{NH}_{3}$ emmisions from UK agriculture (Misselbrook et al., 2005; 2000). Furthermore, it has been estimated that the cost of slurry storage may not justify fecal bacteria reduction by such means (Svoboda, 2003). The requirement to obtain more storage space may also incur additional disadvantages. Those farms deemed to have inadequate storage would need to increase their storage capacity which in turn creates a greater exposed surface area of liquid livestock manure and hence allows for increased rainfall collection. As a result, this would increase the cost of slurry disposal for the farmer. Finally, a worry would be that farmers could become complacent with their storage space; this may result in situations where stores overflow at periods where land application is not feasible (Svoboda, 2003).

\section{Aeration}

This particular manure treatment strategy is primarily used to control odours released from slurries but it can also assist in the reduction of fecally-derived micro-organisms (Svoboda, 2003). Oxygen must be dissolved into slurry to provide an aerobic environment in replacement of an anaerobic system if successful aeration of liquid livestock manure is to occur (Burton, 1998). The technique is also capable of stabilizing organic matter and converting available organic $\mathrm{N}$ to ammonia $\mathrm{N}$. The 
main methods of aerating slurry are through the use of: surface aerators, bubblers, air injectors, plunging jets, sparger aerators and venture (suction) aerators and these can vary in investment cost, aeration capacity and reliability (Burton and Turner, 2003). The process of aeration in slurry tanks should result in a temperature rise but the accompanying rise in $\mathrm{pH}$ during aeration may also play a role in reducing potential pathogen numbers. Others have commented that protozoa are aerobic microbes and the aeration process may therefore promo te protozoan predation of bacterial pathogens (Heinonen-Tanski et al., 1998a). A variety of studies have examined the impact of aeration on microbial populations within slurries, both in the laboratory and within farm scale slurry tanks.

Thermophilic aeration of cattle slurry has been shown to result in a high standard of hygienic quality of livestock slurry, with temperatures of up to $70^{\circ} \mathrm{C}$ resulting after 19 days aeration at ambient temperatures of around freezing. Combining cattle slurry with whey and fruit-jam waste was found to be optimal for composting (HeinonenTanski et al., 2005). A period of 2 to 5 weeks brought about a $>99 \%$ reduction (and in some cases levels dropped below detection limits) of the initial Salmonella population within cattle slurries at the farm scale, following aeration processes (Heininen-Tanski et al., 1998a). In addition, numbers of fecal coliforms (FC) and fecal streptococci (FS) were reduced, though the impact was greater for FC. In another study it was concluded that aeration of liquid slurry in farm tanks at low temperatures effectively reduced levels of Yersinia, Listeria, enterococci and coliphages by over $90 \%$ of the original inoculum (Heinonen-Tanski et al., 1998b). Others have stated that aeration always results in a more rapid decline of bacteria within slurry (Munch et al., 1987). In terms of eliminating protozoan pathogens, aerated cattle slurry has been reported to contain significantly reduced numbers of Cryptosporidium parvum in contrast to unaerated slurry (Svoboda et al., 1997). Similar research has investigated the impact of aeration on viruses in slurry and determined the rate of inactivation of enterovirus to be increased with aeration. A $\log _{10}$ unit drop was observed within $2-4$ days at $20^{\circ} \mathrm{C}$ in contrast to the same level of virus reduction within 300 days at $5^{\circ} \mathrm{C}$ (Lund and Nissen, 1983). The technique can only be effective provided that no fresh slurry is introduced to aerated batches.

Trouble free and effective aeration of cattle slurries may first require both dilution and mechanical separation of the manure (Haygarth et al., 2004). Also, the conditions of the final composted product may allow for the growth of some potential pathogens such as E. coli $\mathrm{O} 157$ and Salmonella if the composting process has been inefficient and organic matter remains poorly stabilised (Jones and Martin, 2003). Other disadvantages of the approach include the production of foam and further details have been published on aeration oxygen transfer, mixing and foam control and aerator performance (Cumby, 1987abc). This aside, aeration is a relatively simple concept and and can prove an effective approach, but, depending on the system used, running costs and capital investment from the farmer can be expensive when compared to other potential manure management strategies (e.g. intensive aeration can require very high capital costs).

\section{Anaerobic digestion}

Anaerobic digestion is a natural process that operates in the absence of oxygen and which facilitates the decomposition and decay of organic matter. Liquid manures will 
undergo anaerobic digestion unless artificially aerated. A more comprehensive evaluation of anaerobic digestion is provided by Monnet, (2003) but a short description is provided in the following. Briefly, micro-organisms are used to decompose organic matter within livestock manures within a confined digester and this will result in the emission of methane and $\mathrm{CO}_{2}$, hence biogas recovery systems are sometimes known as anaerobic digesters. The resulting digestion can increase reactor temperatures into mesophilic or thermophilic ranges, equivalent to $20-45^{\circ} \mathrm{C}$ and $55-70^{\circ} \mathrm{C}$, respectively. Thermophilic anaerobic digestion will provide a higher gas yield in comparison with its mesophilic counterpart, but in turn it requires increased capital investment (Nicholson et al., 2000). Anaerobic digestion has a variety of benefits and under controlled conditions it can manage odour, reduce pathogen numbers, improve nutrient manageability, breakdown organic mass, and be a competitive alternative to lagoon systems (Moser, 1998). Subsequently, it has been described as an holistic manure treatment solution (Wilkie, 2004). Unfortunately, the system is relatively complex and it has been reported that such treatment systems are generally only used by enthusiastic farmers, primarily because of the associated high capital costs (Nicholson et al., 2000) and intensive management required; this is reflected in the low number of UK anaerobic systems adopted (Svoboda, 2003). Nicholson et al. (2000) estimated that the total capital investment required for anaerobic digestion of cattle slurry for the whole of the UK would be in the region of $£ 1300$ million and as such, this is not a realistic option for farms because of the costs involved.

It has been reported that the anaerobic digestion process can result in over a $2 \log _{10}$ decline of pathogen numbers (Moser, 1998). Mesophilic fermentation at $30^{\circ} \mathrm{C}$ for a period of approximately 14 days has been suggested to be sufficient to reduce pathogen content of slurries significantly (Burton and Turner, 2003), though thermophilic will be prove more more efficient in reducing microbe numbers (Martens et al., 1998). Research investigating specifically bacterial pathogens (Salmonella typhimurium, Escherichia coli and Shigella dysenteriae) determined that laboratory scale anaerobic batch digesters eliminated all of these bacteria within 5 to 10 days at temperatures of $35^{\circ} \mathrm{C}$. A fecal bacterium, indicative of potential pathogen presence (Streptococcus fecalis) was more robust, surviving for up to 15 days at $35^{\circ} \mathrm{C}$. At lower temperatures $\left(18-25^{\circ} \mathrm{C}\right)$ all of the bacteria were able to persist for longer periods; 35 days in the case of $S$. fecalis, 20 days for E. coli and $S$. typhimurium and 10 days for $S$. dysenteriae (Kumar et al., 1999). Inc reasing the temperature further, into a thermophilic regime, is reported to impact further on fecal bacteria destruction times during anaerobic digestion (El-Mashad et al., 2003). At a temperature of $53^{\circ} \mathrm{C}$, E. coli and Streptococcus fecalis numbers have been found to decline by $90 \%$ within 0.4 and $1.0 \mathrm{hr}$, respectively (Olsen and Larsen, 1987). In contrast, a laboratory scale digester experiment using mesophilic anaerobic digestion was found to initially reduce $E$. coli, $S$. typhimurium, $Y$. enterocolitica and $L$. monocytogenes numbers rapidly but a $90 \%$ reduction for these bacteria ranged between 0.7 and 0.9 days during batch digestion (Kearney et al., 1993).

Others have highlighted the ineffective role of anaerobic digestion of liquid fractions of flushed dairy manures due to the highly diluted nature of the waste material. This may also be reflected in the greater wealth of research literature for solid rather than liquid manures. For example, there is a wide selection of work describing the impact of anaerobic digestion on fecal micro-organism numbers within biosolids (e.g. Horan 
et al., 2004; Kato et al., 2003; Sahlstrom, 2003; De Leon and Jenkins, 2002; Nielsen and Petersen, 2000). As a solution, researchers at the University of Florida developed a fixed film anaerobic dige stion procedure which represented a high rate anaerobic digestion technology (Wilkie, 2004). Briefly, the method allows for the digestion of the liquid portion of the livestock manure at ambient temperatures. The term 'fixed film' was derived from the use of inert media which was packed into a tank; a consortia of bacteria were able to attach to this and then grow as a biofilm. As liquid manure was passed through the system, the anaerobic layer of biomass broke down organic matter as previously described.

\section{Pasteurization}

Pasteurization involves a heat treatment of livestock slurry that partially sterilises the content. The temperature of the slurry is raised considerably but is below boiling point and generally below the temperature required to denature protein. It is considered a highly effective technique to eradicate potential pathogens from livestock manures and the method involves maintaining the manure at temperatures as high as $70^{\circ} \mathrm{C}$ for 30 minutes or longer. This increase of temperature will also cause the volatilization of odorous slurry compounds. Widespread implementation of this technique in the UK is unlikely due to associated expenses in terms of both capital and running costs (Svoboda, 2003).

\section{Oligolytic treatment}

Literature describing the effectiveness of oligolytic treatment impact on fecal microbes in livestock manures is limited. In brief, oligolysis is an electrolytic approach that is principally used to reduce the odour of stored slurry (Zanardini et al., 2002), particularly that derived from piggeries (Feddes et al., 1998; Ranalli et al., 1996; Yu et al., 1991). However, it has been suggested to have other beneficial effects, one being pathogen removal, because of the bacteriostatic effect of copper ions. Using this approach, small quantities of metal ions, in particular copper, are dissolved in slurry via electrolysis resulting in sterilisation of some microbes.

Oligolysis methods take place within storage tanks and can last several months.

This electrolytic technique works by first reducing the fermentation and/or respiratory activities of microbes present in slurry through the use of copper ions. The fermentation and respiratory activities of cells within slurry are limited because of an electric current that impacts on cellular membrane mechanisms and adenosine 5triphosphate (ATP) synthesis (Skjelhaugen and Donantoni, 1998). A potential onfarm set-up for electrolytic treatment of slurry (Fig. 5) would require a secondary slurry store to allow for the oligolysis phase. The provision of a secondary store will in itself be expensive, as discussed earlier when evaluating the benefits of manure storage.

Some research has shown that oligolytic treatment can result in a $2 \log _{10}$ decline of FC and FS bacteria but this represented only a small reduction of total numbers and left over $10^{4} \mathrm{MPN} \mathrm{L}^{-1}$ within both pig and cattle slurry (Sorliny et al., 1990). Other research has suggested that electrolytic treatment ensures an effective pathogen kill (Skjelhaugen and Donantoni, 1998). However, in this study the electrolytic treatment followed on from an initial aeration procedure and this may have been influential in 
the reduction of pathogen numbers, though the authors do comment that the electrolytic treatment reduced microbial content very quickly. Conversely, other reports have concluded that the approach provided unconvincing results in the reduction of fecal indicator organisms (FIOs) when compared with other methods of potential pathogen control in livestock manures (Svoboda, 2003). Complementary findings were reported in another laboratory based experiment investigating the oligolytic treatment of pig slurry. Oligolysis lasting for 91 days did not result in a significant reduction of pathogenic indicators (Colanbeen and Neukermans, 1992).

Oligolysis requires a high amount of initial capital to set up a farm scale system as shown in the schematic diagram of Figure 5. However, a basic system requires low investment and its simplicity has meant that the approach has benefited from continued interest (Burton and Turner, 2003). Currently, this potential strategy for pathogen control still appears to be under researched in the literature and this was echoed in a recent expert panel survey conducted for the RELU project RES-224-250086 that found that out of 14 experts in the fields of microbiology, manure management and contaminant transfer, only 2 were aware of its use as a mitigation option for reducing pathogen numbers in manures (Unpublished data).

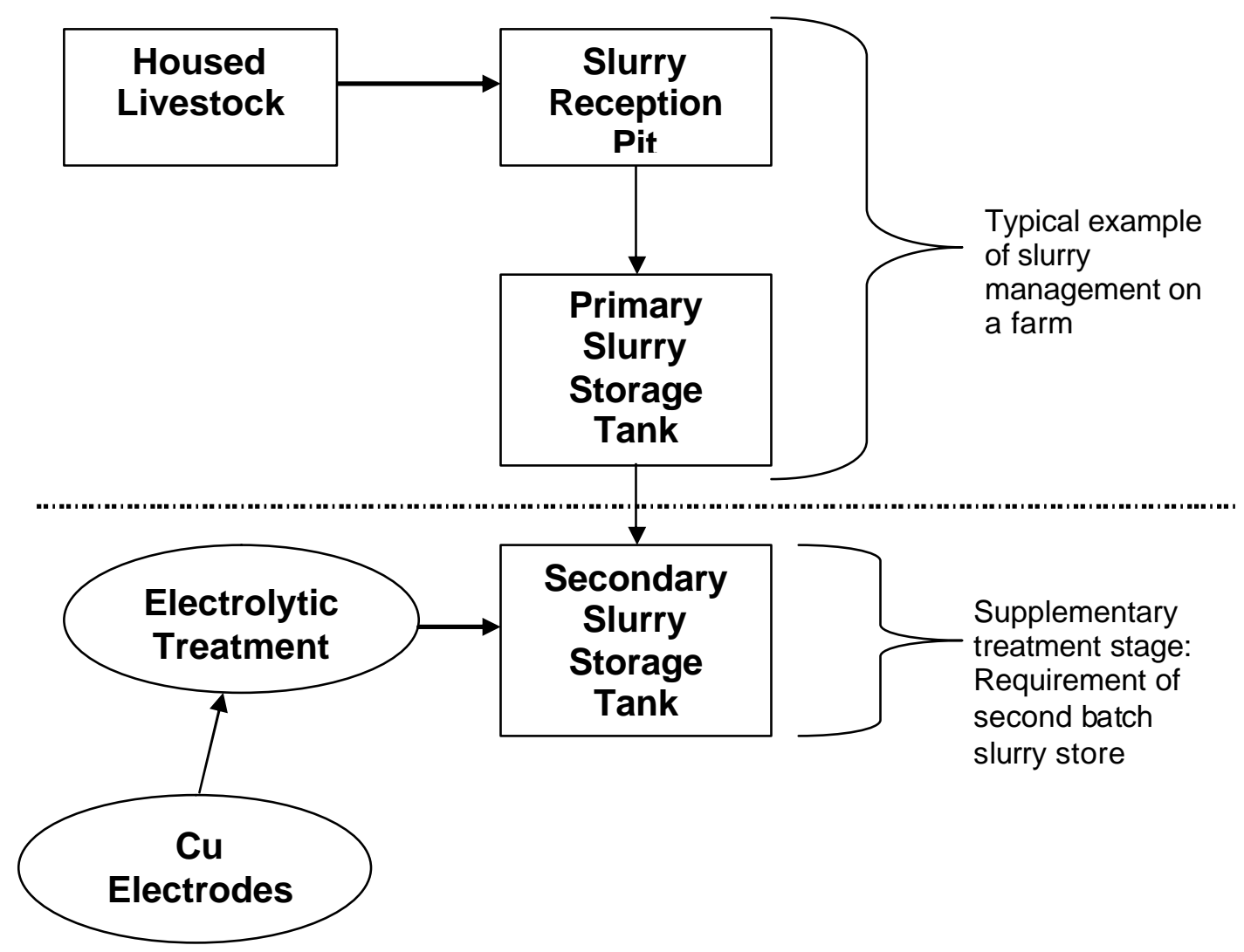

Figure 5: Schematic on-farm design of electrolytic treatment for liquid livestock manure 


\section{Slurry additives and disinfectants}

Slurry additives are not, at present time, widely used in England and Wales (Nicholson et al., 2000) and evidence of their effectiveness is scarce (Burton and Turner, 2003). However, if it can be shown that a range of microbiological benefits can arise from additions to slurries at cost effective rates then it would be advantageous to administer livestock manure additives on a grander scale. Potential additives include strong acids, base precipitating salts and disinfectants. Those substances likely to alter slurry $\mathrm{pH}$ can be expected to be effective for pathogen reduction. Additionally, disinfection of liquid livestock manures may be achieved via the inclusion of chlorate ions to stores; nitrate reductases are known to reduce chlorate ions to form chlorite ions which would impose a bactericidal effect on potential bacterial pathogen populations (Tamasi and Lantos, 1983). Commercially available manure odour control agents have been investigated with respect to their ability to simultaneously impact on E. coli numbers in animal manuress because some of these products claim to reduce pathogens present in swine slurry. One study evaluated ten odour control agents; none were effective at inhibiting or destroying E. coli when supplemented at manufacturer recommended rates (Johnston et al., 2002). Upon mixing the agents with slurry at a ten-fold higher rate, one odour control product (ENVIROPUR) was able to reduce E. coli numbers to levels below detection, even at temperatures as low as $4^{\circ} \mathrm{C}$, and several other products reduced viable $E$. coli levels within the slurry following 8 days incubation (Johnston et al., 2002). Generally, it has been suggested that proprietary additives will have little impact on pathogen survival in slurries (McCrory and Hobbs, 2001).

Lime treatment of slurry can reduce the number of fecal bacteria and potential pathogens through a simple procedure whilst simultaneously providing the added value of a liming agent to livestock manures. Calcium oxide $(\mathrm{CaO})$ and calcium hydroxide $\left(\mathrm{Ca}(\mathrm{OH})_{2}\right)$ are the most commonly used alkaline additives (Svoboda, 2003) and are capable of increasing $\mathrm{pH}$ up to levels of 11.5 and greater. It is reported that achieving a pH of 12, for a minimum of 2 hours is sufficient to result in an effective pathogen decline (D of E, 1996). Alkaline conditions may prove detrimental for fecal bacteria because under such circumstances there exists increased potential for the binding of heavy metals to cell membranes which may inhibit the intra-cellular transfer of a variety of metabolites. The addition of lime will also result in a rise in temperature of the livestock manure, which in itself is detrimental for fecalbacteria survival. Such a temperature rise will also release some odorous slurry compounds. Provided there is an adequate mixing of the lime agent with slurry, fecal microbes can be successfully reduced in number. However, an important point to bear in mind is that the use of lime as a reduction technique is only valid if the land to which slurry is to be applied has a sufficiently low $\mathrm{pH}$ and suitable buffering capabilities to accommodate the lime.

Similarly, acidification of slurry can reduce bacterial numbers, though E. coli O157 has been reported to be more acid tolerant than other potential pathogens (Russel and Jarvis, 2001; Benjamin and Datta, 1995). Acidic conditions help reduce bacterial numbers because of the combined effects of promoting hydrogen ion absorption to cell walls, the inhibition of cation replacement within cells and the potential increase in leakage of compounds essential to normal cell function. The on farm practicalities associated with acid treatment, such as management requirements, safety precautions 
and potential corrosion of steel and concrete stores means that in reality only a specialist contractor would be able to facilitate this management option (Chambers, 2003)

The use of sheep dips in the form of synthetic pyrethroid (SP) insecticides within UK agriculture replaced organophosphate $(\mathrm{OP})$ insecticides after health risks to farmers were associated with the latter. As a result, SP's are now the most commonly used sheep dips within the UK (Semple et al., 2000). Ho wever, SP's are considerably more toxic than OP's for aquatic life-forms (Virtue and Clayton, 1997) and thus sheep dip contamination of watercourses can have detrimental effects on aquatic ecosystems (Hooda et al., 2000). Consequently, a standard disposal strategy is to dilute the sheep dip with animal slurry. In doing so, Semple et al. (2000) found that when high concentrations of sheep dip were diluted with the slurry a significant increase in the FC group, in addition to other bacteria, was observed. Lower concentrations $(0.002-$ $0.02 \%$ ) in contrast had little effect on microbial populations. This led the authors to speculate that sheep dip may be detrimental for protozoa survival thus limiting protozoan grazing on bacteria. A follow up study was able to confirm that the presence of sheep dip formulations in liquid livestock manures was able to reduce the number and diversity of protozoa (Boucard et al., 2004). This highlights the potential for some slurry additives to increase the risk of bacterial contamination of water and land associated with the spreading of liquid livestock manure to pastures.

\section{LIVESTOCK WELFARE}

\section{Animal health}

Most of the pathogens discussed thus far are harmful to humans, and not to the livestock themselves. So although animals may be carriers of these bacteria and protozoa, they do not necessarily show any clinical signs of illness (except in the case of neonatal diarrhoea). This makes it difficult to detect livestock that are carriers of human pathogens. Nonetheless, general livestock health can impact on the microbial composition of livestock feces. Understanding when livestock are susceptible for excreting the highest pathogen loads would clearly aid on-farm pathogen control.

The age, species, diet and management of livestock can impact on pathogen levels found in animal manures (Burton and Turner, 2003). Animals that are exposed to stressful conditions are known to shed higher concentrations of bacteria in their excrement (Jones, 2001; Mechie et al., 1997; Grau et al., 1969). When animals are over-stressed their immune system is inhibited from responding to infection in an efficient and effective manner (de Passille and Rushen, 2005). Inadequate animal housing whereby, for example, large numbers of livestock are confined in small areas, is also likely to enhance the potential for animal-to-animal transfer and pose new health and environmental concerns (Fitzgerald et al. 2003). In general, high stocking densities typical of intensive animal husbandry are likely to increase animal stress levels which may in turn increase the shedding of pathogens and rate of re-infection. As an example, a recent study concluded that high stocking density increased E. coli O157 shedding in beef feedlots (Sargeant et al. 2004). Enhancement of animal welfare through improvements in housing could help limit disease transmission through lower microbial shedding (de Passille and Rushen, 2005). 
Heat stress may also affect fecal shedding rates; in the US, dairy farms that have moved into more warm regions have subjected more cattle to higher temperatures for longer durations (Fitzgerald et al., 2003). Others have claimed that a lack of animal preconditioning combined with long haul transport increased fecal shedding of both generic and pathogenic $E$. coli by calves on, and shortly after, arrival at feedlots (Bach et al., 2004). Similar studies have identified that transportation acted to stress cattle and led to an increase in Salmonella spp. shed in feces (Barham et al., 2002). Shorter transit times and preconditioning may potentially prove effective as management strategies for minimizing pathogen shedding by calves.

\section{Dietary supplementation}

Perhaps a more complex management option is to manipulate the pathogen content of livestock excrement before it is produced. This can be achieved by manipulation of animal diet because of the subsequent alteration of the structure and functions of the gastrointestinal tract (Buddington and Weiher, 1999). There is evidence that pathogen numbers within excrement can be reduced via the supplementation of livestock diet (e.g. Braden et al., 2004; Schamberger et al., 2004). For example, animals fed prior to harvest with an ascophyllum nodosum dietary supplementation experienced a lower prevalence of enterohemorrha gic E. coli $\mathrm{O} 157$ (Braden et al., 2004). A recent review provides a comprehensive account of options available for control of enterohaemorrhagic $E$. coli in ruminants and discusses the use of antibodies, probiotics, fasting and farm management practices (Stevens et al., 2002). However, in conclusion the authors suggest that it is debateable as to whether such strategies can impact on the shedding rates of enterohaemorrhagic $E$. coli sufficiently in order to minimize the risk to human health because of the low dose required to cause infection in humans.

It has been proposed that the introduction of novel forages into agricultural swards can reduce potential pathogen numbers in the animal gut by releasing antimicrobial products on ingestion (Davies et al., 2001). The use of sodium chlorate as a supplement to cattle diet is claimed to reduce E. coli $\mathrm{O} 157$ populations in cattle and be a viable strategy to limit pathogen input to land and livestock manure stores (Callaway et al., 2002). The authors highlight that such a supplementation also reduced generic E. coli numbers and in the case of their study, E. coli declined by 2 orders of magnitude in the rumen. By supplementing drinking water with sodium chlorate for 24 hours all strains of $E$. coli $\mathrm{O} 157$ were reduced by approximately 2 $\log _{10}$ cells in the rumen and $3 \log _{10}$ cells in feces. The reduction in cell numbers occurred because facultative anaerobic bacteria such as E. coli, which are able to anaerobically respire on nitrate through reduction to nitrite, also co-metabolically reduce chlorate to cytotoxic chlorite when exposed to chlorate. Chlorate is only bactericidal against nitrate-reductase-positive bacteria (Callaway et al., 2002) and thus represents a potential strategy to curtail E. coli populations in livestock prior to excretion. Olson et al. (1998) reported that allicin-based products administered to neonatal calves infected with Cryptosporidium parvum did not alter the duration of $C$. parvum induced diarrhoea shedding. However, intensive prophylactic administration of the same product was proposed as being able to delay diarrhoea in calves exposed to $C$. parvum which is also the most frequent aetiologic agent involved in outbreaks of diarrhoea in lambs (Munoz-Fernandez et al. 1996). Colicinogenic E. coli additions to cattle feed are an alternative strategy for reducing fecally shed E. coli $\mathrm{O} 157$ 
(Schamberger et al., 2004). Colicins are antimicrobial proteins and so these bacteria are used as a probiotic. Schamberger et al. (2004) found that feed supplementation of this type resulted in a reduction of $1.1 \log _{10} \mathrm{CFU} \mathrm{g} \mathrm{g}^{-1}$ feces and that a daily administration of $10^{8} \mathrm{CFU}$ of colicin E7 producing $E$. coli to every gram of feed had the potential to limit fecal shedding of this pathogenic E. coli strain.

Other studies have investigated the survival of E. coli $\mathrm{O} 157$ in slurry from cattle fed different diets. As an example, over a ten week slurry storage period, E. coli $\mathrm{O} 157$ was observed to decline in number by 3.5 and $5.5 \log _{10}$ CFU within slurry derived from cattle fed a silage and silage plus concentrate diet, respectively (McGee et al., 2001). Furthermore, a change of diet from grain- to hay-based diet has been proposed as a option to lower the number (and acid resistance) of E. coli within cattle (DiezGonzalez, 1998). This is important because acid tolerant $E$. coli are more likely to survive in the human stomach; if the strain is pathogenic then it may lead to an increased potential of infection of the human host if the bacteria can withstand the acid environment (Couzin, 1998).

However, in the long term, probiotic or dietary ways of controlling potential pathogens may not prove to be consistent and it is likely that farm/land management may also be required to complement such measures. The reason for this is that survival studies in soil, water and manures consistently suggest that outside the host animal, fecal microbes do not survive well. Land/farm management strategies could focus on (i) making the outside environment as un-conducive as possible to survival or (ii) prolonging the residence time of those microbes in the environment that exist in the farm.

\section{LAND MANAGEMENT STRATEGIES TO LIMIT PATHOGEN TRANSFER FROM LAND TO WATER}

Pathogen transfers from land to water can occur through a range of soil hydrological pathways (Oliver et al., 2005a). A key factor governing the transport of microbes from land is high intensity rainfall (Oliver et al., 2005b) but clearly human activity is unable to regulate this driver. In response, there are a variety of methods aimed at limiting micro-organism movement and delivery to watercourses and these are evaluated on a case by case basis in the following. It is critical, however, to emphasize that for optimal mitigation of microbial contamination of watercourses there is a need to develop an holistic and integrated catchment management approach to support sustainable solutions by using strategies that complement one another.

\section{A. MEASURES TO REDUCE PATHOGEN MOBILIZATION FROM LAND}

\section{Manure application techniques}

The discussion in section II identified that spreading of livestock manures to pasture could introduce a source of pathogens to land which may subsequently be transferred through and across the soil when coupled with hydrological drivers such as rainfall. For consideration of how to effectively limit any potential movement in an attempt to protect watercourses from microbial delivery following manure application, attention 
must be given to the timing and rates of application and to the variety of manure application methods at the farmer's disposal. In the UK, Defra funded the production of a series of summary booklets for managing livestock manures, one of which provided valuable information with respect to spreading systems for slurries and solid manures (Chambers et al., 2001).

Application methods for liquid manures include broadcast (splash plate), band, trailing hose and injection techniques. Briefly, broadcast spreading uses pressure to force slurry from the tanker onto an inclined 'splash plate' resulting in a widely distributed topical application of manure to land. Band spreading provides close application to land in the form of narrow bands via a series of hoses connected to a boom at the rear of a slurry tanker. The trailing shoe option is similar to band spreading, except that the shoe attached to each hose facilitates slurry deposition under the sward canopy. Finally, injection methods literally inject slurry under the soil surface - either by means of a shallow or deep injection. For grassland, shallow injectors are used that are able to incorporate slurry to a depth of less than $0.1 \mathrm{~m}$ from the soil surface (Rodhe and Etana, 2005). The most common solid manure spreading techniques are side discharge spreading and rear discharge spreading. Ploughing land following manure spreading effectively incorporates the manure into the soil and can be adopted when reseeding grassland.

Rapid, or incidental, transfers of contaminants can occur following rainfall coupled with ill timed manure applications (Preedy et al., 2001) and this can represent a significant source of bacterial pollution for surface waters (Ramos et al., 2006). Manures (and associated microbes) applied via broadcast techniques without incorporation are likely to be more readily mobilized by surface runoff than those injected or ploughed into the soil because they are less well protected from detachment mechanisms associated with (i) impacting rain drops and (ii) resulting surface runoff processes (Quinton et al., 2003). While the shallow injection and trailing shoe techniques deliver liquid manures in bands under the sward cover and therefore protect the slurry components from rainfall, some studies have found that there is an increased risk of bacteriological contamination of tile drains following injection rather than broadcast spreading (King et al., 1994; Foran and Dean, 1993; Dean and Foran, 1992).

The advice provided to farmers in terms of the best preventative spreading methods to limit microbial contamination is complicated further because of impacts on microbe survival associated with these different spreading methods. Deep injection and ploughing of manures into the soil may be seen as a strategy to aid the protection of watercourses from rapid overland transfers of manures and manure-associated bacteria and protozoa through prohibiting lateral movement, but a direct consequence of incorporation with the soil is that the microbes, such as E. coli O157, persist for longer periods than they would on the soil surface (Avery et al., 2004a). Similarly, Hutchison et al. (2004b) showed that the rate of pathogen decline was governed by the amount of time contaminated manures remained on the soil surface and that microbe viability increased when incorporated with the soil. This may have arisen because the surface injected / ploughed cells were protected from desiccation effects associated with UV radiation, known to be effective for pathogen kill (Hijnen et al., 2006; Meays et al., 2005), but additionally, the soil environment can provide protective micro-niches for microbes (England et al., 1993). However, the 
incorporated location within the soil does not guarantee that the microbe will stay on land; water movement through soil may then facilitate a slower vertical microbial transfer through the soil matrix or rapid passage through bypass pathways (macropores) which may potentially deliver the cells to a watercourse, providing the microbes are not filtered and trapped within the soil profile. So as a counter argument it may be construed that broadcast spreading is the preferred option to protect watercourses from microbial pollution because it allows for a more rapid elimination of microbes through desiccation and UV radiation, effectively removing the pathogen source and preventing microbial contamination. It would, however, be imperative that the manure application be well timed to avoid an immediate rainfall event following application; this is dependent upon the vigilance of the farmer (see Section IV.A.2).

As a final consideration, there must be appreciation that microbial contaminants are not the only environmental concern associated with spreading manures to land. Incorporation techniques are seen as efficient methods to reduce ammonia emissions and nuisance odours following spreading periods (Misselbrook et al., 2002; Moseley et al., 1998; Malgeryd, 1998). Broadcast applications may allow for rapid microbial die-off but do not necessarily benefit other pollution issues, and if coupled with a rainfall event, broadcast spreading can be disastrous for water quality if a watercourse is in close proximity to the land to which the manure has been applied.

\section{Farmer environmental stewardship}

Farmer vigilance can undoubtedly complement even the most effective mitigation efforts. There are a variety of simple options that can be adopted that are proven to offer some means of watercourse protection from contaminants derived from livestock manures. The key to such vigilance essentially lies in the maintenance of fields and farmyards. Simple and often cheap measures can include grazing fields located away from watercourses, separation and diversion of clean water from roofs away from dirty areas of the farmyard, the repair of guttering to facilitate such separation and the relocation of gateways to avoid likely runoff pathways.

Interestingly, a simulation study for the River Irvine catchment in Scotland identified that catchment mitigation approaches may be more beneficial for the microbial quality of bathing water at Irvine Beach than simply reducing stocking density of animals (Vinten et al., 2004b). However, reduced stocking densities will result in less excreta per unit area and this has to be considered as a potential strategy to limit fecal loading of pasture, though in balance it is also associated with additional economic costs because the farmer will be required to either increase the area of farmed land or reduce animal numbers. Removal of animals from pasture prior to rainfall events is probably of little benefit to water quality because pasture will have already been contaminated with excrement and work has reported the importance of the legacy of fecal material on pasture in terms of microbial impact on receiving waters even after the removal of cattle (Oliver et al., 2005b). In addition, the relocation of cattle may impact pasture by creating rapid overland flow pathways from the continually trampled and poached ground as livestock are herded from field to field thus eliminating any benefit of moving the cattle in the first instance. Knowing that bacterial transfer from land to water occurs, an alternative strategy is to remove livestock from susceptible and vulnerable areas of pasture. By mapping such vulnerable areas of pasture (see Section IV.B.4) there may exist the potential to limit 
microbial loading of receiving waters by (i) avoiding overland flow pathways and steep slopes and (ii) including natural vegetation buffers or constructed wetlands as complementary mitigation strategies.

A crucial aspect to consider in relation to manure spreading rather than animal management is the timing of manure applications to land - which, if done carefully and according to CoGAP (MAFF, 1998), can be extremely effective. This is because there is an increased likelihood for bacterial contamination of receiving waters if a rain event occurs soon after slurry application (Ramos et al., 2006). The farmer decision making process ultimately determines when manures are spread to land at particular times throughout the agricultural calendar. Limiting the impacts of a manure application on water quality can be addressed by vigilance on the part of the farmer. However, the practicalities are not always straight forward if storage space is insufficient and farmers are forced to apply manure to land (Aitken, 2003). Earlier in the paper, Section II suggested that batch storage of manure is beneficial for the microbial composition of slurry and solid manure, but it does not prove convenient if storage space is limited. In fact, limited storage space can in some cases dictate application timings. A proportion (up to 16\%) of dairy farms in the UK have insufficient (less than 1 month) storage capacity and therefore the spreading of manure to land almost 365 days a year becomes a necessity (Smith et al., 2001). Other factors may also govern farmer's decisions, such as family tradition and the firmness of the ground to be able to take farm machinery onto pasture in the first instance.

In considering farmyard management strategies, McGechan and $\mathrm{Wu}$ (1998) raise an interesting modelling scenario when discussing slurry storage options for impacts on the environment and farm economics. They adopt two slurry store size options for their simulations, each reflecting a differing farmer attitude to the manure. It follows that a farmer who opts for a small slurry store may consider the slurry to be an embarrassing 'waste' requiring disposal, which will often take place when the store has reached capacity and on fields in closest proximity to the store. In contrast, the authors state that farmers opting for larger slurry stores may represent farmers who consider slurry to be a beneficial 'resource' that can be exploited for their economical gain. The logic behind this is that the slurry can be stored and spread at the optimum time for nutrient uptake by crops so therefore increased storage provides increased flexibility for land application.

A final farmyard management strategy is associated with roof and gutter maintenance. Roofing can constitute a source of non-point water pollution and this will vary with the roofing material, age and slope (Chang et al., 2004). Clean water can transfer from roofing and mix with farmyard washings thus increasing the volume of dirty water sourced from the hard standings. Separation of clean roof water (via guttering) from farmyard areas contaminated with feces will help in reducing dirty water runoff from farmyard areas. 'The 4 point plan' (4 point plan, 2002) published in Scotland is an example of literature distributed to farmers that is aimed, in part, at increasing awareness of how to minimise dirty water accumulation around farmyards via straight forward advice. 


\section{B. MEASURES TO REDUCE PATHOGEN DELIVERY TO WATER}

\section{Restricting livestock access to streams}

Establishing a minimum distance from a watercourse at which animals can graze and thus fencing off such areas is a potential strate gy designed to limit run-off of excrement from nearby pasture and prevent direct cattle access to streams. Fencing off of watercourses can therefore prevent the direct deposition of fecal material into a stream. However, fencing alone cannot guarantee a reduction in pollutant loading to the stream because even fenced fields pose a risk of contributing contamination form overland flow and subsurface drainage contributions to water (Byers et al, 2005; Oliver et al., 2005b; Signor et al, 2005). Any grazed fields that are fenced off from watercourses must then be coupled with the provision of an alternative water source for livestock to drink. It has been reported that it is increasingly unlikely that there will be direct impact on microbial pollution of watercourses caused by animal defecation into surface waters because of farmers attempting to provide animals with drinking water away from rivers and streams (Sheffield et al., 1997). These authors found that the provision of water troughs away from a stream drew cattle away from the watercourse for drinking $92 \%$ of the time, therefore reducing FC concentrations in receiving streams by up to $51 \%$. While this has been shown to reduce $E$. coli contamination of watercourses (Byers et al., 2005) other argue that the effect of an off-stream water source does not satisfactorily prove effective at reducing pollutant loads to water (Line et al., 2003), presumably because excrement can deposited in high concentrations around off-stream drinking areas (White et al., 2001) and this may be mobilised following rainfall. Additionally, cattle will often use streams for loafing in warm weather and so the stream does not only represent a source of drinking water but also a cooling agent during summer months and this will act to further complicate widespread uptake of fenced waterways. Clearly, allowing cattle to drink from a stream is cheaper for the farmer than having to provide alternative water sources, shaded areas and fencing, but it is less sustainable for microbial water quality. The provision of small bridges to allow animal crossings from field to field rather than through streams will also restrict cattle loafing in watercourses but again requires monetary input from a farmer in contrast to cost-free stream fording.

\section{Vegetated buffer strips (VBS)}

Vegetated buffer strips (VBS) are designed to reduce surface flow and their use is widely recognised as a management option to protect watercourses from sediment and particulate phosphorus derived from agricultural land (Hickley and Doran, 2004; Abu-Zreig et al., 2004; Abu-Zreig et al., 2003; Ferguson et al., 2003; Abu-Zreig, 2001; Magette et al., 1989). VBS may also prove effective for removing unwanted bacteria from surface runoff, prior to their delivery to receiving waters from both land receiving manures and grazed pasture. In the UK, CoGAP recommends that a $10 \mathrm{~m}$ buffer be used between manure spreading and a watercourse (MAFF, 1998). However, such an approach is only effective when subsurface pathways of microbial transfer, such as tile drainage, are unimportant. A basic model of the microbial efficiency of VBS is given in Equation 1:

$$
\mathrm{T}_{\mathrm{r}}=\mathrm{M}_{\mathrm{i}}-\mathrm{M}_{\mathrm{o}} / \mathrm{M}_{\mathrm{i}}
$$


where $T_{r}$ is the trapping efficiency of the VBS and $M_{i}$ and $M_{o}$ are the total number of fecal micro-organisms in the inflow and outflow, respectively. A number of studies have reported the varying capacity of VBS to trap microbes in runoff and in general successful filter strips are required to promote infiltration, dilution and sedimentation. Typically, VBS offer optimal efficiency when runoff depth is shallow. A simplified summary of VBS efficiency is shown in Figure 6. 


\begin{tabular}{|c|c|c|c|}
\hline Scenario & Description & $\begin{array}{l}\text { Rainfall event (i) of } \\
\text { intensity } \mathrm{X} \mathrm{mm} \mathrm{hr}^{-1} \\
\text { falls onto fecally } \\
\text { contaminated pasture } \\
\text { generating overland } \\
\text { flow of } A \mathrm{~mm} \text { depth }\end{array}$ & $\begin{array}{l}\text { Rainfall event (ii) of } \\
\text { intensity } 2 \mathrm{Xm} \mathrm{mr}^{-1} \\
\text { falls onto fecally } \\
\text { contaminated pasture } \\
\text { generating overland } \\
\text { flow of } 2 \mathrm{Amm} \text { depth }\end{array}$ \\
\hline \multicolumn{4}{|l|}{1} \\
\hline No Buffer in place & $\begin{array}{l}\text { No buffer is used to } \\
\text { protect watercourse } \\
\text { from wash-in of } \\
\text { fecal bacteria } \\
\text { applied or } \\
\text { deposited onto } \\
\text { pasture of slope } \\
\text { angle } Z^{\circ}\end{array}$ & $\begin{array}{l}\text { Fecal micro-organisms } \\
\text { detected in watercourse }\end{array}$ & $\begin{array}{l}\text { Increased number of fecal } \\
\text { micro-organisms detected } \\
\text { in watercourse relative to } \\
\text { rainfall event (i) }\end{array}$ \\
\hline \multicolumn{4}{|l|}{2} \\
\hline Buffer Strip y & $\begin{array}{l}\text { Buffer strip of } y \\
\text { metres is used to } \\
\text { protect watercourse } \\
\text { adjacent to pasture } \\
\text { of slope angle } Z^{\circ}\end{array}$ & $\begin{array}{l}\text { Reduced number of fecal } \\
\text { micro-organisms are } \\
\text { detected in watercourse } \\
\text { relative to Scenario } 1\end{array}$ & $\begin{array}{l}\text { Increased number of fecal } \\
\text { micro-organisms detected } \\
\text { in watercourse relative to } \\
\text { rainfall event (i) }\end{array}$ \\
\hline \multicolumn{4}{|l|}{3} \\
\hline Buffer St & $\begin{array}{l}\text { Buffer strip of }\left(2^{*} y\right) \\
\text { metres is used to } \\
\text { protect watercourse } \\
\text { adjacent to pasture } \\
\text { of slope angle } Z^{\circ}\end{array}$ & $\begin{array}{l}\text { Reduced number of fecal } \\
\text { micro-organisms are } \\
\text { detected relative to } \\
\text { Scenario } 2\end{array}$ & $\begin{array}{l}\text { Increased number of fecal } \\
\text { micro-organisms detected } \\
\text { in watercourse relative to } \\
\text { rainfall event (i) }\end{array}$ \\
\hline \multicolumn{4}{|l|}{4} \\
\hline Buffer Strip y & $\begin{array}{l}\text { Buffer strip of y } \\
\text { metres is used to } \\
\text { protect watercourse } \\
\text { adjacent to pasture } \\
\text { of slope angle } \\
\left(1.5^{\star} Z\right)^{\circ}\end{array}$ & $\begin{array}{l}\text { Increased number of fecal } \\
\text { micro-organisms are } \\
\text { detected relative to } \\
\text { Scenario } 2\end{array}$ & $\begin{array}{l}\text { Increased number of fecal } \\
\text { micro-organisms detected } \\
\text { in watercourse relative to } \\
\text { rainfall event (i) }\end{array}$ \\
\hline
\end{tabular}

Figure 6: Basic matrix to illustrate buffer strip efficiency for reducing fecal microbe delivery to watercourses. 
Protozoan pathogen attenuation via VBS have been evaluated by Atwill et al. (2002) and Tate et al. (2004) among others. Buffers constructed with silty clay or loam or at lower bulk densities were most successful at filtering the oocysts, in contrast to sandy loams and higher bulk density soils. It was proposed that under certain rainfall and slope conditions, a metre of VBS can produce a 0.9 to $2.0 \log _{10}$ mean reduction in $C$. Parvum oocyst flux relative to the total oocyst load applied in a fecal matrix (Tate et al., 2004). Atwill et al., (2002) concluded that vegetated buffer strips of slope $<20 \%$, soil bulk density of 0.6 to $1.7 \mathrm{~g} \mathrm{~cm}^{-3}$ and of $3 \mathrm{~m}$ width should result in a $3 \log _{10}$ reduction of $C$. parvum oocysts from overland flow that is generated from rainfall events of $<4 \mathrm{~cm} \mathrm{~h}^{-1}$. In another study, a comparison of vegetated and non-vegetated surfaces was made to evaluate the impact on overland and near surface transport of $C$. parvum using tilted soil chambers with bare ground and in contrast with brome vegetation (Trask et al., 2004). Similar to other research, vegetation was found to effectively filter protozoa from surface runoff. Under high intensity rainfall $(63.5 \mathrm{~mm}$ $\mathrm{h}^{-1}$ ), up to $59 \%$ of oocysts were recovered in surface runoff from the bare soil surface in contrast to a maximum of $27 \%$ from the vegetated surface. In conclusion vegetation was proposed as viable management strategy to reduce pathogenic protozoa being delivered to surface waters because of oocyst entrapment within vegetation, adsorption to plant material and infiltration into the soil profile (Trask et al., 2004).

Research which evaluated the impact of the distance of bovine manure from a collection point to demo nstrate the efficacy of VBS in reducing FC bacteria within overland flow found that a vegetated strip of $0.61 \mathrm{~m}$ between feces and stream would reduce the number of FC entering the stream by $83 \%$ in contrast to direct deposition of the fecal matter into the water (Larsen et al., 1994). Increasing the vegetated strip to $2.1 \mathrm{~m}$ increased this reduction of FC by a further $12 \%$. Tate et al. (2006) observed similar findings of increased cell attenuation associated with increased buffer width. They reported that, relative to a $0.1 \mathrm{~m}$ buffer, each additional metre of vegetative buffer can result in a 0.3-3.1 $\log _{10}$ reduction of E. coli discharge for the range of slope, rainfall and runoff conditions investigated. Similarities in FC and phosphorus transfer through short VBS under saturated conditions have been found, leading some to believe that there is potential to evaluate buffer strip performance based on the more substantive volume of literature associated with $\mathrm{P}$ mitigation using vegetated strips (Stout et al., 2005).

A small scale plot experiment $(2.4 \times 30.5 \mathrm{~m})$ whereby the upper $12.2 \mathrm{~m}$ of each plot received manure application and the lower $18.3 \mathrm{~m}$ acted as a VBS was undertaken by Lim et al., (1998). Runoff water was sampled at various filter lengths and concentrations of FC bacteria were reduced from $2 \times 10^{5} \mathrm{FC} \mathrm{mL}^{-1}$ to undetectable levels following runoff passage through $6.1 \mathrm{~m}$ of filter strip (Lim et al., 1998). Field experimentation in New Zealand has found that sloping $\left(8^{\circ}\right)$ grass buffer strips $(5 \mathrm{~m}$ long, $2 \mathrm{~m}$ wide) provided minimal entrapment of E. coli and Campylobacter under high flow events but that under low water application rates entrapment could exceed $95 \%$ of the applied cells (Collins et al., 2004). It was proposed that during large runoff events, a $5 \mathrm{~m}$ length of buffer strip would be required to significantly limit delivery of fecal bacteria to receiving waters. Others have found that the effect of buffer width on E. coli discharge was partly dependent on total runoff volumes (Tate et al., 2006). Interestingly, remobilisation of trapped microbes was also investigated using a subsequent rainfall event after a 5 day interlude and cells were observed to be washed out in the order of 2-3 times lower than recorded at the end of the experiment. 
Ineffectiveness of VBS with respect to limiting fecal bacteria transfer has also been reported (Coyne et al., 1995) leading to debate over the usefulness of such abatement strategies. While $99 \%$ of sediment in runoff was retained by $9 \mathrm{~m}$ long grass filter strips, only $74 \%$ and $43 \%$ of FC were trapped in the two plots studied. Coyne et al. (1995) commented that this was an inadequate filtering efficiency for the protection of receiving waters in accordance with US primary water contact standards, especially following heavy rain and surface runoff. Similarly, Fajardo et al. (2001) concluded that VBS were ineffective at coliform reduction in surface runoff despite other published work supporting significant attenuation of fecal cells in vegetative buffers (Tate et al., 2006).

There are some concerns that VBS may only function effectively for a limited period and that they may even become a source of agricultural contaminants as opposed to functioning as sinks all year round (Osborne and Kovacic, 1993). In response, some researchers have stated that prudent management of vegetation within buffer systems is required, in addition to careful installation and design, to achieve optimal benefits for both the environment and public health (Tate et al., 2006; Atwill et al., 2002; Barling and Moore, 1994).

\section{Riparian buffer strips (RBS)}

Riparian buffer strips (RBS) are seen as a crucial link between agricultural land and the river corridor (Anbumozhi et al., 2005). In some situations, the reduction of diffuse agricultural pollutants being delivered to receiving waters, carried by surface runoff, can be attributed to RBS because of their natural filtering capability of the dense vegetation which can trap fecal matter and reduce the momentum of surface runoff. This management technique is often recommended as a tool for removing diffuse pollutants from agricultural areas (Anbumozhi et al., 2005; Lee et al., 2003). As an example, to protect shellfisheries from fecal bacteria in North Carolina, riparian buffer restoration was recommended as a viable management strategy to implement alongside wetlands and education (White et al., 2000). Modelled scenario analysis has been employed to suggest a potential reduction (in the range of $3-82 \%$; median 35\%) of $E$. coli concentrations in stream waters of the Upper Managaotama catchment, Whatawhata, following the restriction of cattle access to the stream and riparian retirement (Collins and Rutherford, 2004).

In Georgia, on a grassed area of Tifton loamy sand with an adjacent riparian forest of slash pine on a loamy sand, riparian filter strips (30 m long) comprised of $10 \mathrm{~m}$ grass and $20 \mathrm{~m}$ forest prevented a surface-flow wastewater pulse moving beyond $7.5 \mathrm{~m}$ in dry seasons but in wet weather the surface flow pulse was able to reach $30 \mathrm{~m}$ (Entry et al., 2000a). Stream bank engineering as part of the Lake Champlain Basin Program opted to include riparian restoration as part of the devised management strategy to reduce $\mathrm{P}$, sediment and bacterial loads entering the water and as part of a combined mitigation effort (coupled with riparian fencing and protected stream crossings) a significant decline in bacterial counts in the watershed were observed (Meals, 2001). Vegetation in RBS has also been investigated with respect to coliform bacteria survival (Entry et al., 2000b). Following application of animal manure to the RBS, coliform bacteria declined to background levels after 3 to 4 months, though the bacteria declined 10 fold every 1 to 2 weeks, irrespective of seasonality effects. In 
general, higher numbers of FC remained in the upper soil profile $(0-5 \mathrm{~cm})$. Given that shade can facilitate improved survival of bacteria contained within fecal deposits it is possible that riparian zones allow bacteria such as $E$. coli to survive longer than if feces is deposited on open grassland (Meays et al., 2005). It is therefore important to fence off riparian areas not only to prevent cattle poaching, but also to restrict feces being deposited in the riparian area where it remains protected from UV and available for wash-off into adjacent water. If we also consider that the habitat of a riparian zone is likely to be home to a variety of wildlife that can contribute feces and associated bacteria to the vegetation and soil, then even with fencing to protect the riparian zone, wild animals can potentially contaminate the area which is intended to protect the watercourse from fecally derived bacteria.

Ecological engineering aspects of riparian buffer design are discussed by Anbumozhi et al. (2005). Briefly, they note that a time lag will occur between the planting of riparian zone trees and the mature functioning of this buffer for pollutant removal. Clearly, combining a riparian buffer with grass filter stretches and shrubs will allow for additional filtering until trees are fully grown. Other factors such as maintenance and bank stabilisation are also crucial aspects to consider in the design of effective riparian buffers. The topography of the land surrounding RBS clearly needs accounting for as steep slopes dropping to buffers are less likely to function with function efficiently. Alongside maintenance there still remains the issue of practicality; in many instances farmed land is a valuable asset and the use of land to provide a $20 \mathrm{~m}$ riparian buffer may be met with some opposition on economic grounds from farmers. As concluded by Collins and Rutherford (2004), the extent of the efficiency of such a management tool for protecting neighbouring watercourses remains highly uncertain and this can be attributed, in part, to our incomplete understanding of how fecal microbes actually transfer (freely suspended or particulate-associated) through the environment once released from fecal matter. It has also been suggested that it is not wise to focus primarily on RBS as an 'end-ofthe-line' strategy for limiting microbial loading of watercourses (Edwards and Merrilees, 2003) and instead the coupling of several mitigation approaches within an integrated catchment management strategy may offer improved protection.

\section{Land management engineering and vulnerability mapping}

A variety of studies have identified that overland flow can facilitate the transfer of micro-organisms from land to water (e.g. Collins et al., 2005). In response, limiting overland flow may act to reduce (though not eliminate) the delivery of fecal microbes to receiving waters. While there exist a range of methods to reduce such transfers, many of which are evaluated in this paper, there is also an option to engineer the land in a way that benefits both the environment and its users, in a form of proactive intervention (Quinn and Hewett, 2003).

The advent of Geographic Information Systems (GIS) and recent technological developments have accelerated and dramatically improved visual modelling approaches to land management. Hydrological flow paths in agricultural environments can now be mapped with the aid of computer programmes linked with digital elevation and digital terrain models (DEMs and DTMs). Consequently, high resolution digital terrain analysis can be used to highlight zones likely to generate runoff within farmed landscapes. Figure 7 shows the ArcGIS hillshade output of a 5 
m DTM (NextMap Britain) for a small area of the Taw catchment in North Devon, UK. A farm boundary is shown on the map via a solid black line. Even with a basic output as shown in Figure 7 it is possible to make sensible predictions of where overland flow may potentially develop within this example farm environment following rainfall.

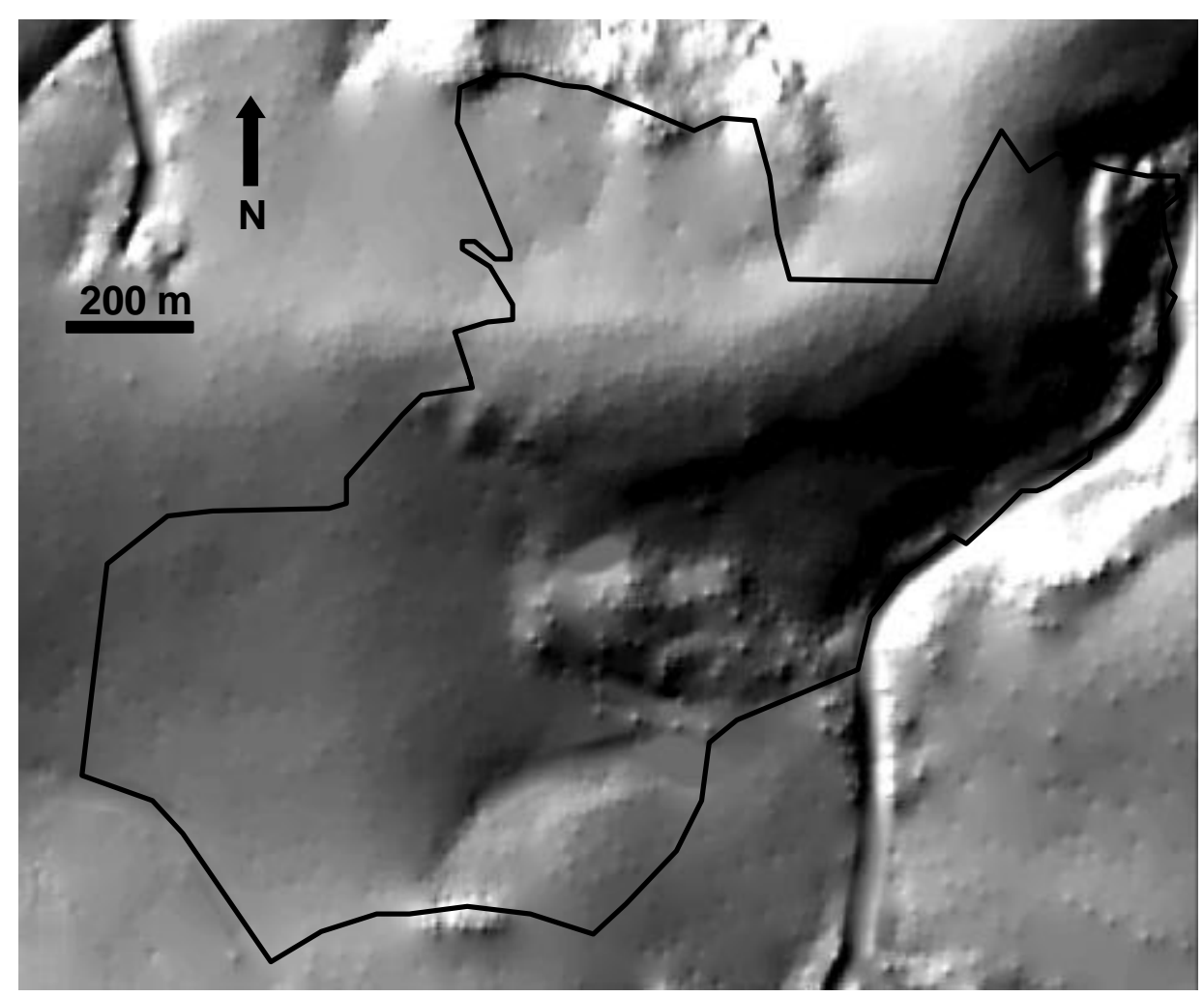

Figure 7: ArcGIS hillshade image of a farm in the UK which can assist the identification of topography and likely flow paths for overland flow. It can be combined with other datasets to help screen for land considered more 'risky' for contributing contaminants from land to water. Solid black line represents the farm boundary

An example of a software tool developed for studying runoff processes at the farm scale is TopManage, which is basically a hydrological / topographical toolkit (Hewett and Quinn, 2003). Briefly, TopManage allows for the representation of local microtopography allowing visualisation of likely runoff zones and enabling a simulation of how manmade features such as tyre tracks from machinery, hedgerows and concrete roads may accelerate or decelerate farm runoff. This can then allow the user to make an informed assessment on the likely impact of such features on water flow from farmed land. TopManage can therefore be used as an integral part of a runoff management plan. More recently, Heathwaite et al. (2005) have discussed modelling and managing critical source areas (CSA's) using flow connectivity simulation through combining CSA's and flow accumulation models. This helped to identify the 
importance of tramlines, tracks and field drains in concentrating flow towards receiving waters. Lane et al., (2004) discussed flow connectivity modelling in terms of a network index approach They suggest that for hydrological connectivity from a saturated zone to a watercourse to occur, then all DEM cells between that saturated zone and the drainage network must become saturated. Within such models assumptions can be made with respect to flow direction of runoff based on contours derived from the base DEM. If a contaminant of concern is known to be transported by surface runoff processes, then being able to predict the location of surface generated flow can be an important landscape screening tool. Discussions relating to the importance of DEM spatial resolution in generating model outputs are provided by Abedini et al., (2006) and Brazier et al. (2005).

An appreciation that complete field characterisation cannot be facilitated through GIS modelling alone is essential. To obtain a more representative understanding we require a combination of field visits, farmer interviews and nationally available datasets at different spatial resolutions to allow for spatially distributed assessments of the risk of surface runoff in the environment. If these options are coupled with the assumption that surface water flows will also act as a carrier for microbial contaminants, the risk of land contributing microbes to water can be gauged in relative terms thus allowing prioritisation of sites for land management (e.g. Lane et $a l$. in press). DEMs are clearly important tools and when coupled with hydrological knowledge and agronomic information (often obtained from farmers) they offer a valuable insight into potential effective management and control of runoff from land. If such landscape engineering can be employed to disconnect flow then the implications are that entrained contaminants will also be disconnected from surface waters.

\section{Constructed wetlands}

A constructed wetland is a biological system engineered to imitate the conditions of a natural wetland and used in the amelioration of wastewater (Nuttall, et al. 1997). Constructed wetlands, or reed beds, are an effective, environmentally passive way to treat effluents and wastewaters of various degrees of potency with relatively low capital and operating costs and minimal maintenance (Collings and Phillips, 2001). They are seen as part of the sustainable development approach to waste management, offering both a low environmental impact and an appropriate ecological option (Hodgson, et al., 2002).

Constructed wetlands are categorised into two main groups; free water surface treatment wetlands (FWS) and subsurface flow treatment wetlands (SSF). In the FWS system the wetland has a water depth up to $0.6 \mathrm{~m}$ with the water surface open to the air. Vegetation and micro-organisms grow in the wetland and act to ameliorate the wastewater, which is often delivered as a constant stream. In this type of reed bed, effluent passes over the support medium, between the macrophyte stems and through any surface litter. In the SSF system the reed bed resembles a percolating filter except it accommodates aquatic plants. The wastewater is introduced in such a way as to cover the surface of the bed and percolate down through the plant rhizospheres and supporting media. By intermittent dosing of the wastewater on to the reed bed sufficient aeration of the support media is maintained to avoid anoxic conditions. 
Constructed wetlands are now considered as fundamental requirements in the design of non-mains sewage treatment systems (Grant et al. 2000). The application of different plant species alongside various designs of macrophyte systems has been the focus of research, with the parameters that constitute the consent standards (Biochemical Oxygen Demand (BOD), Chemical Oxygen Demand (COD), Total Suspended Solids (TSS) and nitrates and phosphates) receiving most attention (Turner, 1995; Nuttall et al., 1997; McNevin et al., 2000; Perkins and Hunter, 2000; Hunt et al., 2002).

Where studies on constructed wetlands have been conducted there is often a lack of information regarding the frequency of sampling and the period of study (Chendorian et al. 1998; Thurston et al. 2001; Quinonez-Diaz et al. 2001). Perkins and Hunter (2000) under took a study on the FWS macrophyte system, they concluded that on average an order of magnitude reduction in concentration of FC and FS was observed between the inflow and outflow of the FWS system, equating to mean removal efficiencies of $86-94 \%$ for FC bacteria and $83-90 \%$ for FS bacteria.

Stenström and Carlander (2001) reported a 99.9\% removal of fecal enterococci as compared to $97.5 \%$ removal for FC, via constructed wetlands, in their Swedish study. Similarly Kay et al. (2005) reported reductions of over $97 \%$ in the flux and concentration of fecal indicator organisms FIOs to marine recreational waters by a natural wetland. Kern et al. (2000) reported removal rates for FC bacteria of $99.3 \%$ in the summer and $95.8 \%$ in the winter in a constructed wetland treating dairy farm wastewaters.

The mechanisms associated with the removal of bacterial indicators are attributable to both biotic and abiotic factors. The biotic factors include predation, die-off and addition from transient and resident animals (water voles; coots; pied wagtails etc.), while the abiotic factors include sedimentation, filtration, adsorption, effluent flow and temperature (Reed et al. 1995; Perkins and Hunter, 2000). Clearly effluent flow has a strong influence on bacterial removal, as borne out by the strong negative correlation observed between bacterial removal and effluent flow (Hodgson et al., 2004) and so at times of high flow, bacterial removal efficiency declines (Green et al., 1997). An explanation for this is that an essential design criterion for wetland systems is to provide conditions conducive to the settlement of particulate associated pollutants. This is achieved through the presence of vegetation which impedes flow, thus allowing the more effective sedimentation of fine particulates $(<2 \mu \mathrm{m}$ in size), which have a slower settling velocity (Davies et al., 2003). Recording the time samples are taken may have a significant outcome on the reported removal efficiency of a wetland. Hodgson et al. (2004) identified a diurnal trough, in terms of removal efficiency, during normal flow conditions. This is perhaps typical of a sewage treatment system dealing predominately with domestic wastewater. This may in part go some way to explaining why so many authors report such high removal efficiencies for constructed wetlands (e.g. Wood and McAtamney, 1994; Kern et al., 2000; Decamp and Warren, 2001; Quinonez-Diaz et al., 2001; Pundsack et al., 2001, Thurston et al. 2001). In each case removal efficiencies in excess of $98.5 \%$ are reported however, no mention of sampling time is indicated. 
The type of planting medium (gravel or soil) can also influence the effectiveness of SSF wetlands in reducing coliform numbers. Decamp and Warren (2000) exemplified both of these cases in a combined microcosm and pilot-scale experiment and found that most $E$. coli removal takes place within the first $1 / 3$ of a system and that $E$. coli did not decline as quickly within unplanted soil bed when compared with gravel bed systems. The relationship between $E$. coli concentration and distance along the bed followed an exponential decline. When scaling up from a microcosm $(1.25 \times 0.3 \mathrm{x}$ $0.25 \mathrm{~m})$ to pilot $(6.0 \times 2.8 \times 0.6 \mathrm{~m})$ study, the average $E$. coli removal increased by at least $24 \%$. This may be attributed to the less efficient communities developed within the microcosms (Decamp and Warren, 2000).

\section{Farm ponds}

Farm ponds may be considered as a viable mitigation measure in providing a sink for contaminants mobilised within surface runoff from pasture (Heathwaite et al., 2005; Quinn et al., 2004; Hawkins and Scholefield, 2003). In contrast, others believe that ponds are a contaminant source within farm environments because of their susceptibility to receive and harbour contaminated surface runoff and fecal droppings (Malaney et al., 1962). In a similar fashion to VBS, RBS and constructed wetlands, farm ponds rely on retention as a mechanism to attenuate fecal microbes. Some work have shown that grazing livestock on land above farm ponds can be advantageous in reducing the rate and number of fecal bacteria entering watercourses (Fisher et al., 2000). In one study, stream water quality was protected because the ponds intercepted TC, E. coli and enterococci bacteria leaving the grazed watershed. It was found that the outflow of microbes from the pond were of similar magnitude to those in surface waters draining a wooded catchment (Fisher et al., 2000). Larger protozoan pathogens can be removed by ponds largely because of sedimentation processes; bacteria in contrast are eliminated more by the processes of $\mathrm{UV}$, high $\mathrm{pH}$ and predation within the pond environment. Pond depth can therefore prove important as it impacts directly on the penetration of UV radiation through the water and also influences dissolved oxygen concentrations (Von Sperling, 2005). In particular, specifically designed waste stabilisation ponds are considered to be effective at removing pathogenic bacteria (Von Sperling, 2005).

Others oppose the value of farm ponds as mitigation options because they argue that ponds simply create another problem whilst trying to minimise the diffuse pollution issue they are intended to alleviate. This may then have to be dealt with in terms of regulation of farm ponds in the future, yet another form of regulation for farmers to adhere to. Jones (2005) has stated that farm ponds are actually a rich source of pathogens for livestock which can effectively lead to a continuous cycle of shedding and ingestion within the farm environment. Perhaps more worryingly, ponds also provide birds with potentially pathogen contaminated water for consumption and bathing. Ingestion of microbes by birds may then allow for the transfer of fecally derived bacteria and protozoa beyond the farm boundary. A study has warned that migratory species could even serve to disperse bacteria between widely separated locations (Cole et al., 2005). This study also speculates that opportunities exist for new health problems in wildlife populations to emerge because birds use farm ponds and waste lagoons and graze on pastures inhabited by cattle and other livestock. Birds do not only pose a threat around farm ponds; their known potential for excretion of a range of human pathogens in droppings means that congregations of birds represent a 
source of environmental pollution whatever their immediate surroundings (Jones, 2005). This can further complicate our assessment of the contribution of agriculture to fecal loading of surface waters.

\section{V.SYNTHESIS AND CONCLUDING REMARKS}

\section{A. CONCEPTUALISING MICROBIAL MITIGATION}

The risk of microbial contamination of watercourses varies with the extent to which a source of pathogens (e.g. manure) is combined with a transfer mechanism (e.g. rainfall and slope) and a delivery component (e.g. hydrological connectivity) to form a continuum which facilitates successful microbial export from land to water. Should a pathogen source be coupled with both a means of transfer and successful delivery to a watercourse, then a potential source becomes an actual risk (Edwards and Merilees, 2003). Conversely, without a source of microbial contaminants, it does not matter if runoff is generated and hydrological connectivity to a stream exists, because no microbes will be carried in the water flow and no microbial contamination of water will result. Similarly, if manure high in pathogen numbers is applied to land, but is located in a field where runoff risk is low and hydrological connectivity to a watercourse is indirect and negligible (i.e. no field drains present and the field is located far from a watercourse) then again, the risk of water contamination is significantly reduced.

In summary, integrated mitigation strategies should be able to successfully limit microbial contamination of watercourses by attempting to remove, or significantly reduce source, transfer or delivery components from a potentially risky agricultural scenario (as summarized in Figure 8) so that large source areas of fecally derived microbes do not coincide with areas prone to the generation of surface runoff or other transfer processes. In more general terms, a mitigation option should aim to remove the contribution of CSA's specific to the contaminant of concern. However, at the same time there is a need to make an holistic assessment of any proposed mitigation strategy. This review has dealt primarily with microbial contaminants but there remains a difficult 'balancing act' for farmers and land managers if they are to embrace successful stewardship of farmed land. The diversity of physical, biological and chemical characteristics associated with the growing suite of agricultural pollutants means that while certain practices may assist in limiting microbial delivery to watercourses, they may in turn accelerate pollution of the environment with other agriculturally derived contaminants ('pollution swapping'). This is highlighted with strategies designed to alleviate $\mathrm{N}$ and $\mathrm{P}$ diffuse pollution. Both contaminants have differing chemistry and flow pathways meaning that mitigation options are often in conflict and liable to compromise water quality remediation (Sharpley et al., 1998). Risk assessment strategies should be considered to assess the benefits of 'pollution swapping' to limit environmental impacts from grassland farming and aid design of holistic frameworks for designing mitigation strategies for agricultural pollutants.

\section{B. CONCLUSIONS}

Agronomic perturbations arising from grassland management and human activities can alter the rural landscape and contribute to temporal and spatial variability in 
pollutant loading of streams. The inherent complexity associated with heterogeneous landscapes confounds the likelihood that a single management strategy will provide complete protection of receiving waters from microbial contamination. Appreciation that a solitary mitigation option cannot deliver $100 \%$ effective mitigation for diffuse microbial pollution needs to remain completely transparent for land managers and it is only with the coupling of different strategies alongside improved education and considerable vigilance by farmers that a more sustainable approach to limiting diffuse microbial (and, crucially, other contaminant) pollution from agriculture can be practiced. An awareness that small farms can adopt simple measures and that larger, more economically stable farms can accommodate more comprehensive multi-stage strategies of mitigation is a fundamental foundation for designing suitable land and manure management plans.

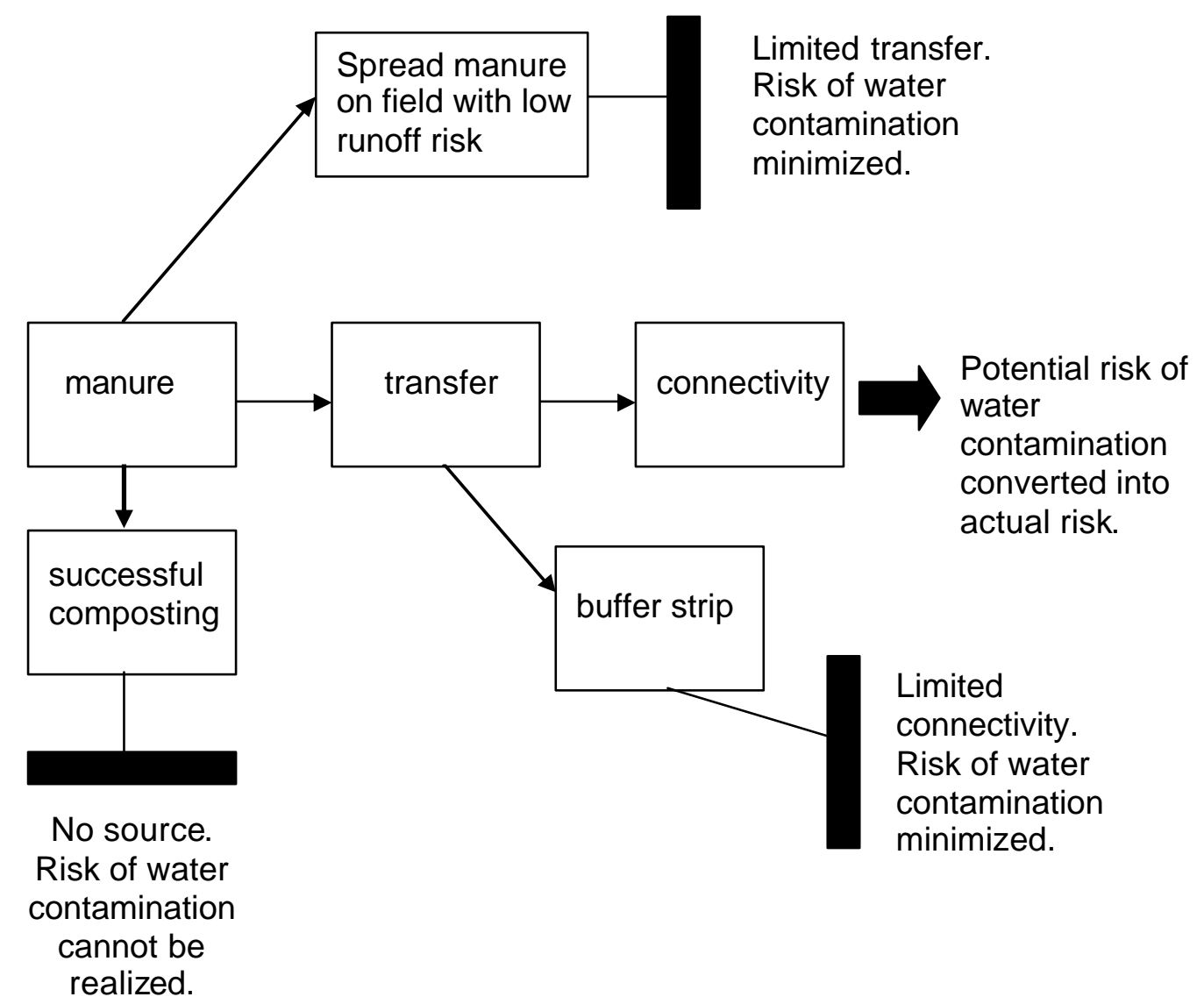

Figure 8: A conceptual flow chart depicting source, transfer and delivery stages of pathogen cycling through the environment. Examples of potential mitigation measures are highlighted as breaking the continuum that would otherwise have allowed for watercourse contamination.

Advances in manure management strategies continue to address the potential problem of diffuse bacterial pollution from an 'upstream' perspective, prior to land application, and undoubtedly further improvements in technology will make for more efficient strategies of manure 'cleansing' in the future. However, no matter how effective the strategy, some microbes of concern are likely to remain available for 
transfer from land to water. Furthermore, we should also question whether it is acceptable for manure particles to enter receiving waters even if fecal pathogens have been removed - the answer is probably not because in reality we do not want to come into contact with fecal matter, sterile or not, in potable water. This means that land management will, and must, remain a key tool in minimizing the hydrologically driven transfer of fecal matter from farmed grassland to adjacent watercourses and this continues to be a challenging area of catchment science, largely because of the complexity of addressing the mitigation of sporadic episodes of overland flow.

Essentially, the quality of our approach to land management should be reflected in the quality of our watercourses. However, this means that cost-effective strategies and land management options need to be widely adopted throughout farmed catchments in order to prevent other neighbouring farms jeopardizing the microbial water quality at the expense of the effort of others. While management options can prove valuable, equally important is the need to transfer such information to the farming community, so that management strategies can be adopted at the farm management level in order to improve the bacteriological quality of water draining catchments and so that results of scientific studies are not wasted.

\section{ACKNOWLEDGEMENTS}

This work was funded as part of project RES-224-25-0086 by the Rural Economy and Land Use (RELU) programme who receive financial support from the Biotechnology and Biological Sciences Research Council (BBSRC), the Natural Environment Research Council (NERC), the Economic and Social Research Council (ESRC), the Department for Environment, Food and Rural Affairs (Defra) and the Scottish Office.

\section{REFERENCES}

Abedini, M. J., Dickinson, W. T., and Rudra, R. P. (2006). On depressional storages: the effect of DEM spatial resolution. J. Hydrol. 318, 138-150.

Abu-Zreig, M., Rudra, R. P., Lalonde, M. N., Whiteley, H. R., and Kaushik, N. K. (2004). Experimental investigation of runoff reduction and sediment removal by vegetated filter strips. Hydrol. Proc. 18, 2029-2037.

Abu-Zreig, M., Rudra, R. P., Whiteley, H. R., Lalonde, M. N., and Kaushik, N. K. (2003). Phosphorus removal in vegetated filter strips. J. Environ. Qual. 32, 613-619.

Abu-Zreig, M. (2001). Factors affecting sediment trapping in vegetated buffer strips: simulation study using VFSMOD. Hydrol. Proc. 15, 1477-1488.

Ahmed, W., Neller, R., and Katouli, M. (2005). Evidence of septic system failure determined by a bacterial biochemical fingerprinting method. J. Appl. Microbiol. 98, 910-920.

Aitken, M. N. (2003). Impact of agricultural practices and river catchment characteristics on river and bathing water quality. Water Sci. Tech. 48, 217224.

Anbumozhi, V., Radhakrishnan, J., and Yamaji, E. 2005. Impact of riparian buffer zones on water quality and associated management considerations. Ecol. Eng. 24, 517-523.

Anon (1976). Council Directive 76/160/EEC concerning the quality of bathing water. Official Journal of the European Communities L31, 1-7. 
Anon (2000). Council directive 2000/60/EC Establishing a framework for the community action in the field of water policy. Official Journal of the European Communities L327, 1-152.

Atwill, E. R., Hou, L. L., Karle, B. A., Harter, T., Tate, K. W., and Dahlgren, R. A. (2002). Transport of Cryptosporidium parvum oocysts through vegetated buffer strips and estimated filtration efficiency. Appl. Environ. Microbiol. 68, 5517-5527.

Avery, L. M., Hill, P., Killham, K., and Jones, D. L. (2004a). Escherichia coli O157 survival following the surface and sub-surface application of human pathogen contaminated organic waste to soil. Soil Biol. Biochem 36, 2101-2103.

Avery, S. M., Moore, A., and Hutchison, M. L. (2004b). Fate of Escherichia coli originating from livestock faeces deposited directly onto pasture. Lett. Appl. Microbiol. 38, 355-359.

Avery, L. M., Killham, K., and Jones, D. L. (2005). Survival of E. coli O157 : H7 in organic wastes destined for land application. J. Appl. Microbiol. 98, 814-822.

Bach, S. J., McAllister, T. A., Mears, G. J., and Schwartzkopf-Genswein, K. S. (2004). Long-haul transport and lack of preconditioning increases fecal shedding of Escherichia coli and Escherichia coli $\mathrm{O} 157$ by calves. J. Food Prot. 67, 672-678.

Bao, J., Giller, P. S., and Stakelum, G. (1998). Selective grazing by dairy cows in the presence of dung and the defoliation of tall grass dung patches. Animal Sci. 66, 65-73.

Barham, A. R., Barham, B. L., Johnson, A. K., Allen, D. M., Blanton, J. R., and Miller, M. F. (2002). Effects of the transportation of beef cattle from the feedyard to the packing plant on prevalence levels of Escherichia coli $\mathrm{O} 157$ and Salmonella spp. J. Food Prot. 65, 280-283.

Barling, R. D., and Moore, I. D. (1994). Role of buffer strips in management of waterway pollution - a review. Environ. Manage. 18, 543-558.

Benjamin, M. M., and Datta, A. R. (1995). Acid tolerance of enterohemorrhagic Escherichia coli. Appl. Environ. Microbiol. 61, 1669-1672.

Boucard, T. K., Parry, J., Jones, K., and Semple, K. T. (2004). Effects of organophosphate and synthetic pyrethroid sheep dip formulations on protozoan survival and bacterial survival and growth. FEMS Microbiol. Ecol. 47, 121-127.

Braden, K. W., Blanton, J. R., Allen, V. G., Pond, K. R., and Miller, M. F. (2004). Ascophyllum nodosum supplementation: A preharvest intervention for reducing Escherichia coli O157:H7 and Salmonella spp. in feedlot steers. J. Food Prot. 67, 1824-1828.

Brazier, R. E., Heathwaite, A. L., and Liu, S. (2005). Scaling issues relating to phosphorus transfer from land to water in agricultural catchments. J. Hydrol. 304, 330-342.

Buddington, R. K., and Weiher, E. (1999). The application of ecological principles and fermentable fibres to manage the gastrointestinal tract ecosystem. $J$. Nutrit. (Suppl.) 129, 1446s-1450s.

Burton, C. H., and Turner, C. (2003). Manure Management: treatment strategies for sustainable agriculture $2^{\text {nd }}$ edition. Silsoe Research Institute, Bedford, UK.

Burton, C. H. (1998). Processing Strategies for organic wastes. Proceedings of the 8th international Conference on the FAO ESCORENA Network on Recycling of Agricultural, Municipal and Industrial Residues in Agriculture (Formerly 
Animal Waste Management). Rennes, France, 26-29 May 1998. Available online at http://www.ramiran.net/doc98/FIN-ORAL/BURTON.pdf.

Byers, H. L., Cabrera, M. L., Matthews, M. K., Franklin, D. H., Andrae, J. G., radcliffe, D. E., McCann, Kuykendall, H. A., Hoveland, C. S., and Calvert, V. H. (2005). Phosphorus, sediment and Escherichia coli loads in unfenced streams of the Georgia Piedmont, USA. J. Environ. Qual. 34, 2293-2300.

Callaway, T. R., Anderson, R. C., Genovese, K. J., Poole, T. L., Anderson, T. J., Byrd, J. A., Kubena, L. F., and Nisbet, D. J. (2002). Sodium chlorate supplementation reduces E. coli $\mathrm{O} 157$ : $\mathrm{H} 7$ populations in cattle. J. Animal Sci. 80, 1683-1689.

Chadwick, D. R., and Chen, S. (2002). Manures. In "Agriculture, Hydrology and Water Quality" (P. M. Haygarth and S. C. Jarvis, eds.), pp. 57-82. CAB International, Wallingford and New York.

Chambers B.J., Nicholson R.J., Smith K., Pain B.F., Cumby T.R., and Scotford I.M. (2001) Managing Livestock Manures: Booklet 3 - Spreading systems for slurries and solid manures. 18 pp. Defra, Noble House, Smith Square, London SW1P 3JR.

Chambers, B. J. (2003). Implications of potential measures to control pathogens associated with livestock manure management. Final contract report to Defra, project WA0656. 49pp.

Chang, M., McBroon, W., and Beasley, R. S. (2004). Roofing as a source of nonpoint water pollution. J. Environ. Manage. 73, 307-315.

Chendorian, M., Yates, M., and Villegas, F. (1998). The fate and transport of viruses through surface water constructed wetlands. J. Environ. Qual. 27, 1451-1458.

Colanbeen, M., and Neukermans, G. (1992). Oligolytic treatment of piggery slurry. Landbouwtijdschrift-Revue De L Agriculture 45, 701-716.

Cole, D., Drum, D. J. V., Stallknecht, D. E., White, D. G., Lee, M. D., Ayers, M., Sobsey, M., and Maurer, J. J. (2005). Free-living Canada geese and antimicrobial resistance. Emerg. Inf. Dis. 11, 935-938.

Collins, R., Elliot, S., and Adams, R. (2005). Overland flow delivery of faecal bacteria to a headwater pastoral stream. J. Appl. Microbiol. 99, 126-132.

Collins, R., Donnison, A., Ross, C., and McLeod, M. (2004). Attenuation of effluentderived faecal microbes in grass buffer strips. New Zeal. J. Ag. Res. 47, 565574.

Collins, R. and Rutherford, K. (2004). Modelling bacterial water quality in streams draining pastoral land. Water Res. 38, 700-712.

Collings, J. M., and Phillips, C. A. (2001). Bacteriocin-like inhibition of Bacillus subtilis by an indigenous reed bed bacterium. World J. Microbiol Biotech. 17. 321-324.

Couzin, J. (1998). Microbiology - Cattle diet linked to bacterial growth. Science 281, 1578-1579.

Coyne, M. S., Gilfillen, R. A., Rhodes, R. W., and Blevins, R. L. (1995). Soil and fecal coliform trapping by grass filter strips during simulated rain. J. Soil Water Cons. 50, 405-408.

Crowther, J. Wyer, M. D., Bradford, M., Kay, D., Francis, C., A., and Knisel, W. G. (2003). Modelling faecal indicator concentrations in large rural catchments using land use and topographic data. J. Appl. Microbiol., 94, 962-973.

Crowther, J., Kay, D., and Wyer, M. D. (2002). Faecalindicator concentrations in waters draining lowland pastoral catchments in the UK: relationships with land use and farming practices. Water Res. 36, 1725-1734. 
Crowther, J., Kay, D., and Wyer, M. D. (2001). Relationships between microbial water quality and environmental conditions in coastal recreational waters: The Fylde coast, UK. Water Res., 35, 4029-4038.

Cumby, T. R. (1987a). A review of slurry aeration 1. Factors affecting oxygen transfer. J. Ag. Eng. Res. 36, 141-156.

Cumby, T. R. (1987b). A review of slurry aeration 2. Mixing and foam control. J. Ag. Eng. Res. 36, 157-174.

Cumby, T. R. (1987c). A review of slurry aeration 3. Performance of aerators. J. Ag. Eng. Res. 36, 175-206.

Department of the Environment (1996). Code of practice fro agricultural use of sewage sludge. Department of the Environment, Second Edition.

Davies, C. M., Yousefi, Z., and Bavor, H. J. (2003) Occurrence of coliphages in urban stormwater and their fate in stormwater management systems. Lett. Appl. Microbiol. 37, 299-303.

Davies, D. R., Bakewell, E. L., Nash, R. J., and Merry, R. J. (2001). An investigation into the anti-microbial activity of plant extracts against Escherichia coli, Salmonella typhimurium and Listeria monocytogenes. In "Proceedings of society of chemical Industry conference on pathogens in agriculture and the environment, London".

Decamp, O., and Warren, A. (2001). Abundance, biomass and viability of bacteria in wastewaters: impact of treatment in horizontal subsurface flow constructed wetlands. Water Res. 35 (14), 3496-3501.

Decamp, O., and Warren, A. (2000). Investigation of Escherichia coli removal in various designs of flow wetlands used for wastewater treatment. Ecol. Eng. 14, 293-299.

Dean, D. M. and Foran, M. E. (1992). The effect of farm liquid waste on tile drainage. J. Soil Water Cons. 47, 368-369.

de Graaf, D. C., Vanopdenbosch, E., Ortega-Mora, L. M., Abbassi, H., and Peeters, J. E. (1999). A review of the importance of cryptosporidiosis in farm animals. International Journal for Parasitology 29, 1269-1287.

De Leon, C., and Jenkins, D. (2002). Removal of fecal coliforms by thermophilic anaerobic digestion processes. Water Sci. Tech. 46, 147-152.

de Passille, A. M., and Rushen, J. (2005). Food safety and environmental issues in animal welfare. Rev. Sci. Tech. Off. Int. Epiz. 24, 757-766.

Diez-Gonzalez, F., Callaway, T. R., Kizoulis, M. G., and Russell, J. B. (1998). Grain feeding and the dissemination of acid-resistant Escherichia coli from cattle. Science 281, 1666-1668.

Edwards, T., and Merrilees, D. W. (2003). Best management practices aimed at reducing summer microbial loading to rivers: a review. Report to the Scottish Executive, UK. Available online at: http://www.scotland.gov.uk/Resource/Doc/1057/0002226.pdf.

El-Mashad, H. M., van Loon, W. K. P., and Zeeman, G. (2003). A model of solar energy utilisation in the anaerobic digestion of cattle manure. Bios. Eng. 84, 231-238.

England, L. S., Lee, H., and Trevors, J. T. (1993). Bacterial survival in soil - effect of clays and protozoa. Soil Biol. Biochem. 25, 525-531.

Entry, J. A., Hubbard, R. K., Thies, J. E., and Fuhrmann, J. J. (2000a). The influence of vegetation in riparian filterstrips on coliform bacteria: I. Movement and survival in water. J. Environ. Qual. 29, 1206-1214. 
Entry, J. A., Hubbard, R. K., Thies, J. E., and Fuhrmann, J. J. (2000b). The influence of vegetation in riparian filterstrips on coliform bacteria: II. Survival in soils. J. Environ. Qual. 29, 1215-1224.

Fajardo, J. J., Bauder, J. W., and Cash, S. D. (2001). Managing nitrate and bacteria in runoff from livestock confinement areas with vegetative buffer strips. J. Soil Water Conserv. 56, 185-191.

Feddes, J. J. R., Wang, Y., Edeogu, I. E., and Coleman, R. N. (1998). Oligolysis: effect of voltage on odour and sulphide removal in stored pig manure. Canadian Ag. Eng. 40, 113-120.

Ferguson, C., Altavilla, N., Ashbolt, N. J., and Deere, D. A. (2003). Prioritizing watershed pathogen research. J. Am. Water Works Assoc. 95, 92-102.

Fèvre, E. M., Bronsvoort, B. M. de C., Hamilton, K. A., and Cleaveland, S. (2006). Animal movements and the spread of infectious diseases. TRENDS Microbiol. 14, 125-131.

Finstein, M. S. (2004). Protecting watersheds from Cryptosporodium in manure: A literature review. J.Am. Water Works Assoc. 96, 114-116.

Fisher, D. S., Endale, D. M., and Steiner, J. L. (2000). Farm ponds and associated riparian buffers for limiting the movement of $E$. coli and enterococci bacteria from grazing lands. $p$ 24, Riparian Buffer Conference, $22^{\text {nd }}$ May, McKimmon Center, NCSU, Raleigh, NC.

Fitzgerald, A. C., Edrington, T. S., Looper, M. L., Callaway, T. R., Genovese, K. J., Bischoff, K. M., McReynolds, J. L., Thomas, J. D., Anderson, R. C., and Nisbet, D. J. (2003). Antimicrobial susceptibility and factors affecting the shedding of E. coli O157:H7 and Salmonella in dairy cattle. Lett. Appl. Microbiol. 37, 392-398.

Fitzpatrick, G. E., Worden, E. C., and Vendrame, W. A. (2005). Historical development of composting technology during the 20th century. Horttechnology 15, 48-51.

Foran, M. E., and Dean, D. M. (1993). The land application of liquid manure and its effect on tile drain water and groundwater quality. In: Agricultural Research to Protect Water Quality. Proceedings of the conference February 21-26, 1993, Minneapolis, Minnesota. Soil and Water Conservation Society, Ankheny, Iowa, USA, pp. 279-281.

Forshell, L. P., and Ekesbo, I. (1993). Survival of Salmonellas in composted and not composted solid animal manures. Journal of Veterinary Medicine Series BZentralblatt Fur Veterinarmedizin Reihe B-Infectious Diseases and Veterinary Public Health 40, 654-658.

Friend, T. H. (1991). Behavioural aspects of stress. J. Dairy Sci. 74, 292-303.

Gerba, C. P., and Smith, J. E. (2005). Sources of pathogenic micro-organisms and their fate during land application of wastes. J. Environ. Qual. 34, 42-48.

Goss, M. J., Ogilvie, J. R., Beauchamp, E. G., Stonehouse, D. P., Miller, M. H., and Parris, K. (1994). Current state of the art of manure / nutrient management. COESA Report No.: RES/MAN-001/94 prepared for Research Branch. Agriculture and Agri-Food Canada.

Goss, M. J., Zwart, P. D., and Kachanoski, R. G. (2004). Transport of nitrogen, phosphorus and disease organisms from manure into surface and groundwater in Managing Manure for Dairy and Swine - Towards developing a decision support system. Goss, M. J., Stonehouse, D. P and Giraldez, J. C (Eds). 
Grant, N. Moodie, M., and Weedon, C. (2000) Sewage solutions: answering the call of nature. The Centre for Alternative Technology Publications, Powys, UK. pp 52-57.

Grau, F. H., Brownlie, L. E., and Smith, M. G. (1969). Effects of food intake on numbers of Salmonellae and Escherichia coli in rumen and faeces of sheep. $J$. Appl. Bact. 32, 112-117.

Green, M. B., Griffin, P. Seabridge, J. K., and Dhobie, D. (1997). Removal of bacteria in subsurface flow wetlands. Water Sci. Tech. 35, 109-116.

Hawkins, J., and Scholefield, D. S. (2003). "Scoping the potential of farm ponds to provide environmental benefits" DEFRA Final Report ESO109.

Haygarth, P. M., Chadwick, D., Granger, S., Chambers, B., Anthony, S., Smith, K., and Harris, D. (2004). Characteristic behaviour and potential mitigation of some diffuse pollutants in England and Wales: a review of biological oxygen demand, ammonium, nitrate and some potential pathogens.

Heathwaite, A. L., Quinn, P. F., and Hewett, C. J. M. (2005). Modelling and managing critical source areas of diffuse pollution from agricultural land using flow connectivity simulation. J. Hydrol. 304, 446-461.

Heinonen-Tanski, H., Kiuru, T., Ruuskanen, J., Korhonen, K., Koivunen, J., and Ruokojarvi, A. (2005). Thermophilic aeration of cattle slurry with whey and / or jam wastes Bioresource Tech. 96, 247-252.

Heinonen-Tanski, H., Leinonen, P., Niskanen, E. M., Mielonen, M. M., Rasanen, H., Valta, T., Rinne, K., and Joki-Tokola, E. (1998a). Aeration improves the hygiene of cattle slurry and the quality of grass forage and silage. Acta Agriculturae Scandinavica Section B-Soil and Plant Science 48, 212-221.

Heinonen-Tanski, H., Niskanen, E. M., Salmela, P., and Lanki, E. (1998b). Salmonella in animal slurry can be destroyed by aeration at low temperatures. J. Appl. Microbiol. 85, 277-281.

Hewett, C. J. M., Quinn, P. F., Whitehead, P. G., Heathwaite, A. L., and Flynn, N. J. (2004). Towards a nutrient export risk matrix approach to managing agricultural pollution at source. Hydrol. Earth Sys. Sci. 8, 834-845.

Hewett, C., and Quinn, P. (2003). TopManage: A high resolution GIS digital terrain analysis tool to study the management of flows on farms. p. 10-25 to 10-28. In Diffuse pollution and basin management. Proc 7th Int. Specialised IWA Conference., Dublin. 17-22 August 2003. IWA, London.

Hickey, M. B. C., and Doran, B. (2004). A review of the efficiency of buffer strips for the maintenance and enhancement of riparian ecosystems. Water Qual. Res. J. Canada 39, 311-317.

Hijnen, W. A. M., Beerendonk, E. F., and Medema, G. J. (2006). Inactivation credit of UV radiation for viruses, bacteria and protozoan (oo)cysts in water: a review. Water Res. 40, 3-22.

Himathongkham, S., Bahari, S., Riemann, H., and Cliver, D. (1999). Survival of Escherichia coli $\mathrm{O} 157$ : $\mathrm{H} 7$ and Salmonella typhimurium in cow manure and cow manure slurry. FEMS Microbiol. Lett. 178, 251-257.

Hobbs, P. J., Noble, R., Williams, J. S., and Dobrovin-Pennington, A. (2004) Quantifying odour emission from composting. 11th International Conference of the FAO ESCORENA Network on Recycling of Agricultural, Municipal and Industrial Residues in Agriculture (RAMIRAN), Murcia, Spain, 6-9 October 2004. 
Hodgson, C. J., Perkins, J., and Labadz, J. C. (2004). The use of microbial tracers to monitor seasonal variations in effluent retention in a constructed wetland. Water Res. 38, 3833-3844.

Hodgson, C. J., Perkins, J., and Labadz, J. (2002). The potential use of biotracers to monitor effluent retention in a free water surface (FWS) constructed wetland. www.iwaponline.com/wio/2002/07/wio/042.htm. IWA Publishing.

Hooda, P. S., Edwards, A. C., Anderson, H. A., and Miller, A. (2000). A review of water quality concerns in livestock farming areas. Sci. Total Environ. 250, 143-167.

Horan, N. J., Fletcher, L., Betmal, S. M., Wilks, S. A., and Keevil, C. W. (2004). Dieoff of enteric bacterial pathogens during mesophilic anaerobic digestion. Water Res. 38, 1113-1120.

Hunt, P.G., Poach, M.E., Szo gi, A.A., Reddy, G.B., and Humenik, F.J. (2002) Treatment of swine wastewater in constructed wetlands. In: Treatment Wetlands for water Quality Improvement. Quebec 2000 Conference Proceedings (selected papers), CH2MHILL Canada.

Hutchison, M. L., Walters, L. D., Moore, A., and Avery, S. M. (2005a). Declines of zoontoic agents in liquid livestock wastes stored in batches on-farm. J. Appl. Microbiol. 99, 58-65.

Hutchison, M. L., Walters, L. D., Avery, S. M., and Moore, A. (2005b). Decline of zoontoic agents in livestock waste and bedding heaps. J. Appl. Microbiol. 99, 354-362.

Hutchison, M. L, Walters, L. D., Avery, S. M., Synge, B. A., and Moore, A. (2004a). Levels of zoonotic agents in British livestock manures. J. Appl. Microbiol. 39, 207-214.

Hutchison, M. L., Walters, L. D., Moore, A., Crookes, K. M., and Avery, S. M. (2004b). Effect of length of time before incorporation on survival of pathogenic bacteria in livestock wastes applied to agricultural soil. Appl. Environ. Microbiol. 70, 5111-5118.

Johnston, D., Chapman, R., Masse, D., and Topp, E. (2002). Evaluation of commercial odor control agents for suppressing Escherichia coli in swine manure slurry. J. Environ. Qual. 31, 2120-2123.

Jones, K. (2005). Flying hazards: birds and the spread of disease. Microbiol. Today, 32 174-178.

Jones, K. (2002). UK bathing waters: a success story, but....there may be trouble ahead. Microbiol. Today 29, 186-188.

Jones, K. (2001). Campylobacters in water, sewage and the environment. J. Appl. Microbiol. 90, 1-12.

Jones, P. W. (1976). Effect of temperature, solids content and $\mathrm{pH}$ on survival of Salmonellas in cattle slurry. British Vet. J. 132, 284-293.

Jones, P., and Martin, M. (2003). 'A review of the literature on the occurrence and survival of pathogens of animals and humans in green compost'. The waste and resources action programme, Oxon.

Jones, P. W., Smith, G. S., and Bew, J. (1977). Effect of microflora in cattle slurry on survival of Salmonella dublin. British Vet. J. 133, 1-8.

Judge, J., Greig, A., Kyriazakis, I., and Hutchings, M. (2005). Ingestion of faeces by grazing herbivores - risk of inter-species disease transmission. Agric. Eco. Environ. 107, 267-274. 
Kato, S., Fogarty, E., and Bowman, D. D. (2003). Effect of aerobic and anaerobic digestion on the viability of Cryptosporidium parvum oocysts and Ascaris suum eggs. International J. Environ. Health Res. 13, 169-179.

Kay, D., Wyer, M. D., Crowther, J., Wilkinson, J. Stapleton, C., and Glass, P. (2005). Sustainable reduction in the flux of microbial compliance parameters from urban and arable land use to coastal bathing waters by a wetland ecosystem produced by a marine flood defence structure. Water Res. 39, 3320-3332.

Kay, D., Wyer, M. D., Crowther, J., and Fewtrell, L. (1999). Faecal indicator impacts on recreational waters: budget studies and diffuse source modelling. J. Appl. Microbiol., 85, 70S-82S.

Kearney, T. E., Larkin, M. J., Frost, J. P., and Levett, P. N. (1993). Survival of pathogenic bacteria during mesophilic anaerobic digestion of animal waste. $J$. Appl. Bact. 75, 215-219.

Kern, J., Idler, C., and Carlow, G. (2000) Removal of faecal coliforms and organic matter from dairy wastewater in a constructed wetland under changing climate conditions. J. Environ. Sci. Health A35, 1445-1461.

King, D. J., Watson, G. C., Wall, G. J., and Grant, B. A. (1994). Effects of tillage on the quality and quantity of surface and subsurface drainage water: Uplands Final Report. Soil Water Environment Enhancement Program - technical evaluation and development subprogram project. University of Guelph, Ontario, Canada.

Kovacs, F., and Tamasi, G. (1979). Survival times of bacteria in liquid manure. Acta Veterinaria Academiae Hungaricae 27, 47-54.

Kudva, I. T., Blanch, K., and Hovde, C. J. (1998). Analysis of Escherichia coli O157 : $\mathrm{H} 7$ survival in ovine or bovine manure and manure slurry. Appl. Environ. Microbiol. 64, 3166-3174.

Kumar, R., Gupta, M. K., and Kanwar, S. S. (1999). Fate of bacterial pathogens in cattle dung slurry subjected to anaerobic digestion. World J. Microbiol. Biotech. 15, 335-338.

Lane, S. N., Brookes, C. J., Kirkby, M. J., and Holden, J. (2004). A network-indexbased version of TOPMODEL for use with high-resolution digital topographic data. Hydrol. Proc. 18, 191-201.

Lane, S. N., Brookes, C. J., Heathwaite, A. L., and Reaney, S. (in press). Surveillant science: challenges for the management of rural environments emerging from the new generation diffuse pollution models. J Agric. Econ.

Larney, F. J., Yanke, L. J., Miller, J. J., and McAllister, T. A. (2003). Fate of coliform bacteria in composted beef cattle feedlot manure. J. Environ. Qual. 32, 15081515.

Larsen, R. E., Miner, J. R., Buckhouse, J. C., and Moore, J. A. (1994). Water quality benefits of having cattle manure deposited away from streams. Biores. Tech. 48, 113-118.

Lee, K. H., Isenhart, T. M., and Schultz, R. C. (2003). Sediment and nutrient removal in an established multi-species riparian buffer. J. Soil Water Conserv. 58, 1-8.

Lewis, D. J., Atwill, E. R., Lennox, M. S., Hou, L., Karle, B., and Tate, K. W. (2005). Linking on-farm dairy management practices to storm-flow faecal coliform loading for California coastal watersheds. Environ. Mon. Assess. 107, 407425.

Lim, T. T., Edwards, D. R., Workman, S. R., Larson, B. T., and Dunn, L. (1998). Vegetated filter strip removal of cattle manure constituents in runoff. Trans. ASAE 41, 1375-1381. 
Line, D. E. (2003). Changes in a stream's physical and biological conditions following livestock exclusion. Trans ASAE 46, 287-293.

Lund, E., and Nissen, B. (1983). The survival of enteroviruses in aerated and unaerated cattle and pig slurry. Agric. Wastes 7, 221-233.

MAFF. (1998). Code of Good Agricultural Practice for the Protection of Water (The Water Code). Ministry of Agriculture, Fisheries and Food. London, UK.

Magette, W. L., Brinsfield, R. B., Palmer, R. E., and Wood, J. D. (1989). Nutrient and sediment removal by vegetated filter strips. Trans. ASAE 32, 663-667.

Malaney, G. W., Weiser, H. H., Turner, R. O., and Van Horn, M. (1962). Coliforms, Enterococci, Thermodurics, Thermophiles, and Psychrophiles in untreated farm pond waters. Appl. Microbiol. 10, 44-51.

Malgeryd, J. (1998). Technical measures to reduce ammonia losses after spreading of animal manure. Nutrient Cycl. Agroecosys. 51, 51-57.

Martens, W., Fink, A., Phillip, W., Weber, W., Winter, D. and Bohm, R. (1998). Inactivation of viral and bacterial pathogens in large scale slurry treatment plants. In Proceedings from Ramiran $988^{\text {th }}$ International Conference on Management Strategies for Organic Waste Use in Agriculture, pp. 529-39.

Maule, A. (1999). Environmental aspects of E. coli O157. Int. Food Hyg. 9, 21-23.

McCrory, D. F., and Hobbs, P. J. (2001). Additives to reduce ammonia and odour emissions from livestock wastes: a review. J. Environ. Qual. 30, 345-355.

McGechan, M. B., and Wu, L. (1998). Environmental and economic implications of some slurry management options. J. Ag. Eng. Res. 71, 273-283.

McGee, P., Bolton, D. J., Sheridan, J. J., Earley, B., and Leonard, N. (2001). The survival of Escherichia coli $\mathrm{O} 157$ : $\mathrm{H} 7$ in slurry from cattle fed different diets. Lett. Appl. Microbiol. 32, 152-155.

McNevin, D., Harrison, M., King, A., David, K., and Mitchell, C. (2000). Towards an integrated performance model for subsurface flow constructed wetlands. J.Environ. Sci. Health A35(8), 1415-1429.

Meals, D. W. (2001). Water quality response to riparian restoration in an agricultural watershed in vermont, USA. Water Sci. Tech. 43, 175-182.

Meays, C. L., Broersma, K, Nordin, R., and Mazumder, A. (2005). Survival of Escherichia coli in beef cattle faecal pats under different levels of solar exposure. Rangeland Ecol. Manage. 58, 279-283.

Mechie, S. C., Chapman, S. A., and Siddons, C. A. (1997). A fifteen month study of Escherichia coli O157:H7 in a dairy herd. Epidemiol. Inf. 118, 17-25.

Michel, F. C., Pecchia, J. A., Rigot, J., and Keener, H. M. (2005). Mass and nutrient losses during the composting of dairy manure amended with sawdust or straw. Compost Science and Utilization 12, 323-334.

Misselbrook, T. H., Brookman, S. K. E., Smith, K. A., Cumby, T., Williams, A. G., and McCrory, D. F. (2005). Crusting of stored dairy slurry to abate ammonia emissions: pilot-scale studies. J. Environ. Qual. 34, 411-419.

Misselbrook, T. H., Smith, K. A., Johnson, R. A., and Pain, B. F. (2002). Slurry application techniques to reduce ammonia emissions: results of some UK field-scale experiments. Bios. Eng., 81, 313-321.

Misselbrook, T. H., van der Weerden, T. J., Pain, B. F., Sarvis, S. C., Chambers, B. J., Smith, K. A., Phillips, V. R., and Demmers, T. G. M. (2000). Ammonia emission factors for UK agriculture. Atmos. Environ 34, 871-880.

Mohaibes, M., and Heinonen-Tanski, H. (2004). Aerobic thermophillic treatment of farm slurry and food wastes. Biores. Tech.95, 245-254. 
Monnet, F. (2003). An introduction to anaerobic digestion of organic wastes. Remade Scotland Final Report, available online at http://www.remade.org.uk/Organics/organics_documents/IntroAnaerobicDige stion.pdf.

Moseley, P. J., Misselbrook, T. H., Pain, B. F., Earl, R., and Godwin, R. J. (1998). The effect of injector tine design on odour and ammonia emissions following injection of bio-solids into arable cropping. J. Ag. Eng. Res. 71, 385-394.

Moser, M. A., Mattocks, R. P., Gettier, S., and Roos, K. (1998). Benefits, costs and operating experience at seven new agricultural anaerobic digesters. U.S. Environmental Protection Agency, AgStar Program. 7 p. http://www.epa.gov/agstar.

Munch B., Errebo-Larsen, H., and Aalbaek, B. (1987). Experimental studies on the survival of pathogenic and indicator bacteria in aerated and nonaerated cattle and pig slurry. Biol. Wastes 22, 49-65.

Munoz-Fernandez, M., Alvarez, M., Lanza, I., and Carmenes, P. (1996). Role of enteric pathogens in the aethiology of neonatal diarrhoea in lambs and goat kids in Spain. Epidemiol. Inf. 117, 203-211.

Nielsen, B., and Petersen, G. (2000). Thermophilic anaerobic digestion and pasteurisation. Practical experience from Danish wastewater treatment plants. Water Sci. Tech. 42, 65-72.

Nicholson, F. A., Groves, S. J., and Chambers, B. J. (2005). Pathogen survival during livestock manure storage and following land application. Biores. Tech. 96, 135-143.

Nicholson, F. A., Hutchison, M. L., Smith, K. A., Keevil, C. W., Chambers, B. J., and Moore, A. (2000) A Study On Farm Manure Applications To Agricultural Land And An Assessment Of The Risks Of Pathogen Transfer Into The Food Chain. Final report for MAFF project FS2526.

Nicholson, R.J., Webb, J., Wilkinson, M., Moore, A., Moorhouse, D., Elson, A., and Barrow, B. (1999). Future strategies to minimise the environmental effects of slurry and manure storage. MAFF Report WA0657.

Norman, M. J. T., and Green, J. O. (1958). The local influence of cattle dung and urine upon the yield and botanical composition of permanent pasture. $J$. British Grass. Soc. 13, 39-45.

Nuttall, P. M., Boon, A. G., and Rowell, M. R. (1997) Review of the design and management of constructed wetlands. CIRIA report 180.

Oliver, D. M., Clegg, C. D., Haygarth, P. M., and Heathwaite, A. L. (2005a). Assessing the potential for pathogen transfer from grassland soils to surface waters. Adv. Agron. 85, 125-180.

Oliver, D. M., Heathwiate, A. L., Haygarth, P. M., and Clegg, C. D. (2005b). Transfer of Escherichia coli to water from drained and undrained grassland after grazing. J. Environ. Qual. 34, 918-925.

Oliver, D. M. (2005). Hydrological pathways and processes of Escherichia coli transfer from grassland soils to surface waters. PhD thesis, The University of Sheffield, UK.

Olsen, J. E., and Larsen, H. E. (1987). Bacterial decimation times in anaerobic digestions of animal slurries. Biol. Wastes 21, 153-168.

Olson, E. J., Epperson, W. B., Zeman, D. H., Fayer, R., and Hildreth, M. B. (1998). Effects of an allicin-based product on cryptosporidiosis in neonatal calves. $J$. Am. Vet. Med. Assoc. 212, 987-990. 
Osborne, L. L., and Kovacic, D. A. (1993). Riparian vegetated buffer strips in water quality restoration and stream management. Freshwater Biol. 29, 243-258.

Pain, B., and Menzi, H. (2003). Glossary of terms on livestock manure management. RAMIRAN. Swiss College of Agriculture, Laenggasse, Zollikofen, Switzerland.

Pell, A. N. (1997). Manure and microbes: public and animal health problem? J. Dairy Sci. 80, 2673-2681.

Perkins, J., and Hunter, C. (2000). Removal of enteric bacteria in a surface flow constructed wetland in Yorkshire, England. Water Res. 34, 1941-1947.

Pickup, R. W., Rhodes, G., Arnott, S., Sidi-Boumedine, K., Bull, T., Weightman, A., Hurley, M., and Hermon-Taylor, J. (2005). Mycobacterium avium subsp. paratuberculosis in the catchment area and water of the River Taff in South Wales, United Kingdom, and its potential relationship to clustering of Crohn's disease cases in the city of Cardiff. Appl. Environ. Microbiol. 71, 2130-2139.

Preedy, N., McTiernan, K., Matthews, R., Heathwaite, L., and Haygarth, P. (2001). Rapid incidental phosphorus transfers from grassland. J. Environ. Qual. 30, 2105-2112.

Pundsack, J., Axler, R., Hicks, R., Henneck, J., Normand, D., and McCarthy (2001). Seasonal pathogen removal by alternative on-site wastewater treatment systems. Water Environ. Res. 73(2) 204-212.

Quinonez-Diaz, M. D., Karpiscak, M. M., Ellman, E. D., and Gerba, C. P. (2001). Removal of pathogenic and indicator organisms by a constructed wetland receiving untreated domestic wastewater. J. Environ. Sci. Health Part AToxic/Hazardous Substances \& Environmental Engineering 36 (7), 13111320.

Quinton, J. N., Tyrell, S. F., and Ramos, M. C. (2003). The effect of incorporating slurries on the transport of faecal coliforms in overland flow. Soil Use Manage.19, 185-186.

Quinn, P. F., Hewett, C. J. M., and Doyle, A. (2004). Scale appropriate modelling: from mechanisms to management in Scales in Hydrology and Water Management, IAHS Publication 287, Oxfordshire.

Quinn, P., and Hewett, C. (2003). An earth systems engineering approach to the direct management of runoff flow paths and nutrient remediation at source. p. 3-77 to 3-81. In Diffuse pollution and basin management. Proc 7th Int. Specialised IWA Conference., Dublin. 17-22 August 2003. IWA, London.

Ramos, M. C., Quinton, J. N., and Tyrell, S. F. (2006). Effects of cattle manure on erosion rates and runoff water pollution by faecal coliforms. J. Environ. Manage. 78, 97-101.

Ranalli, G., Chiumenti, R., Donantoni, L., and Sorlini, C. (1996). Electrolytic treatment of swine liquid manure in a full scale experiment. J Environ. Sci. Health Part A- Environmental Science and Engineering \& Toxic and Hazardous Substance Control 31, 1705-1721.

Reed, S. C., Crites, R. W., and Midlebrooks, E. J. (1995). Natural systems for waste management and treatment. McGraw-Hill Inc., New York.

Risse, L. M., Bass, T. M., and Ritz, C. W. (2005). A Review of Georgia's AFO Regulations. The University of Georgia College of Agricultural and Environmental Sciences http://pubs.caes.uga.edu/caespubs/pubs/PDF/B1257.pdf

Rodhe, L., and Etana, A. (2005). Performance of slurry injectors compared with band spreading on three Swedish soils with ley. Bios. Eng. 92, 107-118. 
Ryan, U. M., Bath, C, Robertson, I., Read C., Elliot, A., McInnes, L., Traub, R., and Besier, B. (2005). Sheep may not be an important zoonotic reservoir for Cryptosporidium and Giardia parasites. Appl. Environ. Microbiol. 71, 49924997.

Russel, J. B., and Jarvis, G. N. (2001). Practical mechanisms for interrupting the orat fecal lifecycle of Escherichia coli. J. Mol. Microbiol. Biotech. 3, 265-272.

Sahlstrom, L. (2003). A review of survival of pathogenic bacteria in organic waste used in biogas plants. Biores. Tech. 87, 161-166.

Sargeant, J. A., Sanderson, M. W., Smith, R. A., and Griffin, D. D. (2004). Associations between management, climate, and Escherichia coli $\mathrm{O} 157$ in the faeces of feedlot cattle in the midwestern USA. Prev. Vet. Med. 66, 175-206.

Schamberger, G. P., Phillips, R. L., Jacobs, J. L., and Diez-Gonzalez, F. (2004). Reduction of Escherichia coli $\mathrm{O} 157: \mathrm{H} 7$ populations in cattle by addition of colicin E7-producing E. coli to feed. Appl. Environ. Microbiol. 70, 6053-6060.

Semple, K. T., Hughes, P., Langdon, C. J., and Jones, K. (2000). Impact of synthetic pyrethroid-sheep dip on the indigenous microflora of animal slurries. FEMS Microbiol. Lett. 190, 255-260.

Sharpley, A., Gburek, W., and Heathwaite, L. (1998). Agricultural phosphorus and water quality: sources, transport and management. Agric. Food Sci. Finland 7, 297-314.

Sheffield, R. E., Mostaghimi, S., Vaughan, D. H., Collins, E. R., and Allen, V. G. (1997). Off-stream water sources for grazing cattle as a stream bank stabilization and water quality BMP. Trans. ASAE 40, 595-604.

Signor, R. S., Roser, D. J., Ashbolt, N. J., and Ball, J. E. (2005). Quantifying the impact of runoff events on microbiological contaminant concentrations entering surface drinking waters. J. Water Health 3, 453-468.

Skjelhaugen, O. J., and Donantoni, L. (1998). Combined aerobic and electrolytic treatment of cattle slurry. J. Ag. Eng. Res. 70, 209-219.

Smith, K. A., Brewer, A. J., Dauven, A., and Wilson, D. W. (2000). A survey of the production and use of animal manures in England and Wales. I. Pig manure. Soil Use Manage. 16, 124-132.

Smith, K. A., Brewer, A. J., Dauven, A., and Wilson, D. W. (2001). A survey of the production and use of animal manures in England and Wales. III. Cattle manures. Soil Use Manage. 17, 77-87.

Sorliny, C., Ranalli, G., Chiumenti, R, and Donantonni, L. (1990). Study of the oligolytic treatment applied to livestock manure at real scale plants. Final report on results, Milano / Padova.

Soupir, M. L., Mostaghimi, S., Yagow, E. R., Hagedorn, C., and Vaughan, D. H. (2006). Transport of fecal bacteria from poultry litter and cattle manures applied to pastureland. Water, Air Soil Poll. 169, 125-136.

Stanley, K. N., Wallace, J. S., and Jones, K. (1998). Thermophilic campylobacters in dairy slurries on Lancashire farms: seasonal effects of storage and land application. J. Appl. Microbiol. 85, 405-409.

Stevens, M. P., van Diemen, P. M., Dziva, F., Jones, P. W., and Wallis, T. S. (2002). Options for the control of enterohaemorrhagic Escherichia coli in ruminants. Microbiol. 148, 3767-3778.

Stenström, T. A., and Carlander A. (2001) Occurrence and die-off of indicator organisms in the sediment in two constructed wetlands. Water Sci. Tech. 44, 223-230. 
Stout, W. L., Pachepsky, Y. A., Shelton, D. R., Sadeghi, A. M., Saporito, L. S., and Sharpley, A. N. (2005). Runoff transport of faecal coliforms and phosphorus released from manure in grass buffer conditions. Lett. Appl. Microbiol. 41, 230-234.

Svoboda, I. F., Read, I. A., Kemp., J. S. Wright, S. E., Coop, R. L., Mawdsley, J. L., Bardgett, R. D., Merry, R., Pain, B. F., Theodorou, M. K., Bukhari, Z., and Smith, H. V. (1997). Cryptosporidium on cattle farms in Cryptosporidium in water - the challenge to policy makers and water managers. Symposium by Chartered Institute of Water and Environmental Management, Glasgow, pp 320.

Svoboda, I. F. (2003). "Provision of research and design of pilot schemes to minimise livestock pollution to the water environment in Scotland. QLC 9/2. Anaerobic digestion, storage, oligolysis, lime, heat and aerobic treatment of livestock manures. Final report, FEC Services Ltd, Stoneleigh Park, Kenilworth, Warwickshire, CV8 2LS."

Tamasi, G., and Lantos, Z. (1983). Influence of nitrate reductases on survival of Escherichia-coli and Salmonella enteritidis in liquid manure in the presence and absence of chlorate. Agric. Wastes 6, 91-97.

Tate, K. W., Das Gracas, M., Pereira, M. D. C., and Atwill, E. R. (2004). Efficacy of vegetated buffer strips for retaining Cryptosporidium parvum. J. Environ. Qual. 33, 2243-2251.

Tate, K. W., Atwill, E. R., Bartolome, J. W., and Nader, G. (2006). Significant Escherichia coli attenuation by vegetative buffers on annual grasslands. $J$. Environ. Qual. 35, 795-805.

Thelin, R., and Gifford, G. F. (1983). Faecal coliform release patterns from faecal material of cattle. J. Environ. Qual. 12, 57-63.

The 4 Point Plan. (2004). Available online at www.sac.ac.uk/4pp.

Thurston, J. A., Gerba, C. P., Foster, K. E., and Karpiscak, M. M. (2001). Fate of indicator micro-organisms, Giardia and Cryptosporidium in subsurface flow constructed wetlands. Water Res. 35, 1547-1551.

Tiquia, S. M., Tam, N. F. Y., and Hodgkiss, I. J. (1998). Salmonella elimination during composting of spent pig litter. Biores. Tech. 63, 193-196.

Trask, J. R., Kalita, P. K., Kuhlenschmidt, M. S., Smith, R. D., and Funk, T. L. (2004). Overland and near-surface transport of Cryptosporidium parvum from vegetated and nonvegetated surfaces. J. Environ. Qual. 33, 984-993.

Turner, M. K. (1995). Engineered reed-bed systems for wastewater treatment. Trends Biotech. 13, 248-252.

Van Herk, F. H., McAllister, T. A., Cockwill, C. L., Guselle, N., Larney, F. J., Miller, J. J., and Olson, M. E. (2004). Inactivation of Giardia cysts and

Cryptosporidium oocysts in beef feedlot manure by thermophilic windrow composting. Compost Science \& Utilization 12, 235-241.

Vinneras, B., Bjorklund, A., and Jonsson, H. (2003). Thermal composting of faecal matter as treatment and possible disinfection method - laboratory-scale and pilot-scale studies. Biores Tech. 88, 47-54.

Vinten, A. J. A., Douglas, J. T., Lewis, D. R., Aitken, M. N., and Fenlon, D. R. (2004a). Relative risk of surface water pollution by $E$. coli derived from faeces of grazing animals compared to slurry application. Soil Use Manage. 20, 1322. 
Vinten, A. J. A., Lewis, D. R., McGechan, M., Duncan, A., Aitken, M., Hill, C. and Crawford, C. (2004b). Predicting the effect of livestock inputs of E. coli on microbiological compliance of bathing waters. Water Res. 38, 3215-3224.

Virtue, W. A., and Clayton, J. W. (1997). Sheep dip chemicals and water pollution. Sci. Tot. Environ. 194, 207-217.

Von Sperling, M. (2005). Modelling of coliform removal in 186 facultative and maturation ponds around the world. Water Res. 39, 5261-5273.

White, N. M., Line, D. E., Potts, J. D., Kirby-Smith, W, Doll, B., and Hunt, W. F. (2000). Jump Run Creek shellfish restoration project. J. Shellfish Res. 19, 473-476.

White, S. L., Sheffield, R. E., Washburn, S. P., King, L. D., and Green, J. T. (2001). Spatial and time distribution of dairy cattle excreta in an intensive pasture system. J. Environ. Qual. 30, 2180-2187.

Wilkie, A. C., Castro, H. F., Cubinski, K. R., Owens, J. M., and Yan, S. C. (2004). Fixed-film anaerobic digestion of flushed dairy manure after primary treatment: Wastewater production and characterisation. Bios. Eng. 89, 457471.

Wilkinson, J., Kay, D., Wyer, M., and Jenkins, A. (2006). Processes driving the episodic flux of faecal indicator organisms in streams impacting on recreational and shellfish harvesting waters. Water Res. 40, 153-161.

Wither, A., Greaves, J., Dunhill, I., Wyer, M., Stapleton, C., Kay, D., Humphrey, N., Watkins, J., Francis, C., McDonald, A., and Crowther, J. (2005a). Estimation of diffuse and point source microbial pollution in the Ribble catchment discharging to bathing waters in the north west of England. Water Sci. Tech. 51, 191-198.

Wood, B., and McAtamney, C. (1994) The use of macrophytes in bioremediation. Biotech. Adv. 12 653-662.

Xiao, L. H., Herd, R. P., and Rings, D. M. (1993). Diagnosos of Cryptosporidium on a sheep farm with neonatal diarrhoea by immunofluorescence assays. Vet. Parasit.47, 17-23.

Yu, J. C., Isaac, C. E., Coleman, R. N., Feddes, J. J. R., and West, B. S. (1991). Odorous compounds from treated pig manure. Canadian Agric. Eng. 33, 131136.

Zanardini, E., Valle, A., Gigliotti, C., Papagno, G., Ranalli, G., and Sorlini, C. (2002). Laboratory-scale trials of electrolytic treatment on industrial wastewaters: Microbiological aspects. J. Environ. Sci. Health Part A - Toxic / Hazardous Substances and Environmental Engineering 37, 1463-1481. 